NBER WORKING PAPER SERIES

\title{
INCOME AND WEALTH EFFECTS ON PRIVATE-LABEL DEMAND: EVIDENCE FROM THE GREAT RECESSION
}

\author{
Jean-Pierre Dubé \\ Günter J. Hitsch \\ Peter E. Rossi \\ Working Paper 21446 \\ http://www.nber.org/papers/w21446 \\ NATIONAL BUREAU OF ECONOMIC RESEARCH \\ 1050 Massachusetts Avenue \\ Cambridge, MA 02138 \\ August 2015
}

We are grateful to Ron Borkovsky, Bart Bronnenberg, Avi Goldfarb, Ernan Haruvy, Emir Kamenica, Ryan Kellogg, Puneet Manchanda, Kanishka Misra, Sridhar Moorthy, Matt Osborne, and Brian Ratchford for helpful comments and suggestions. We also benefited from the comments of seminar participants at the 2014 Marketing Insights at Chicago Booth Conference, the 2015 Marketing and Economics Summit, the European Commission, UC Davis, the University of Michigan, the University of Toronto, and UT Dallas. We also benefitted from the financial support of MSI Research Grant \#4-1765 and a grant from the IGM at the Chicago Booth School. The views expressed herein are those of the authors and do not necessarily reflect the views of the National Bureau of Economic Research.

NBER working papers are circulated for discussion and comment purposes. They have not been peerreviewed or been subject to the review by the NBER Board of Directors that accompanies official NBER publications.

(C) 2015 by Jean-Pierre Dubé, Günter J. Hitsch, and Peter E. Rossi. All rights reserved. Short sections of text, not to exceed two paragraphs, may be quoted without explicit permission provided that full credit, including $(\mathcal{C}$ notice, is given to the source. 
Income and Wealth Effects on Private-Label Demand: Evidence From the Great Recession Jean-Pierre Dubé, Günter J. Hitsch, and Peter E. Rossi

NBER Working Paper No. 21446

August 2015

JEL No. D1,D12,E21,E3,L0,L00,L1,L10,L11,L16

\begin{abstract}
We measure the causal effects of income and wealth on the demand for private-label products. Prior research suggests that these effects are large and, in particular, that private-label demand rises during recessions. Our empirical analysis is based on a comprehensive household-level transactions database matched with price information from store-level scanner data and wealth data based on local house value indices. The Great Recession provides a key source of the variation in our data, with a large and geographically diverse impact on household incomes over time. We estimate income and wealth effects using "within" variation of income and wealth at the household level. Our estimates can be interpreted as income and wealth effects consistent with a consumer demand model based on utility maximization. We establish a precisely measured negative effect of income on private-label shares. The effect of wealth is negative but not precisely measured. However, the estimated effect sizes are small, in contrast with prior academic work and industry views. An examination of the possible supply-side response to the recession shows only small changes in the relative price of national-brand and private-label products. Our estimates also reveal a large positive trend in private-label shares that predates the Great Recession. We examine some possible factors underlying this trend, but find no evidence that this trend is systematically related to specific private-label quality tiers or to the overall rate of private-label versus national-brand product introductions.
\end{abstract}

Jean-Pierre Dubé

University of Chicago

Booth School of Business

5807 South Woodlawn Avenue

Chicago, IL 60637

and NBER

jdube@chicagobooth.edu

Günter J. Hitsch

University of Chicago

Booth School of Business

5807 South Woodlawn Avenue

Chicago, IL 60637

guenter.hitsch@ChicagoBooth.edu
Peter E. Rossi

UCLA/Anderson School

110 Westwood Plaza B4.12

Los Angeles, CA 90095

peter.rossi@anderson.ucla.edu 


\section{Introduction}

Private-label products are an important component of retail strategy and correspondingly a concern for national-brand manufacturers. A growing area of interest is the extent to which the demand for private-label products is sensitive to income and wealth. A key question is whether private-label products are inferior goods, such that household demand for private-label products decreases in the level of income or wealth.

The question of income and wealth effects on private-label demand has received renewed attention during and after the Great Recession (the NBER dates this recession from December 2007 to June 2009). Some industry sources (see, for example, Nielsen 2011) have claimed that private-label shares increased by over two percentage points on a base of about twenty percent during the recession. Some industry insiders attributed this increase to the recession. According to Mike Moriarty, a partner at AT Kearney: "Generally speaking, if a recession lasts more than 6 months, retailers can expect to see more of a switch to private labels" (Wong 2008). Describing a recent private-label purchase survey, Chris Urinyi, CEO of Lightspeed Research, concludes: "The economic recession is causing an increase in private-label purchasing, a trend that our survey results show is unlikely to change after economic recovery" (Frank 2010). Professor Jan-Benedict Steenkamp reports: "We've done studies spanning decades, and what we document, very clearly, is that private label grows a lot in recessions" (Hammerbeck 2008). Quelch and Harding (1996) assert that "... private-label market share generally goes up when the economy is suffering and down in stronger economic periods." Some prominent academic work on private-label demand over the business cycle supports the notion that private-label demand increases due to a decline in income or wealth. For example, Lamey, Deleersnyder, Dekimpe, and Steenkamp (2007) estimate that a one percent decline in real per capita GDP leads to a permanent increase in the private-label-share annual growth rate of 1.22 percentage points.

The large income effects thought to characterize private-label demand and the evidence on the growth of the overall private-label share during the Great Recession suggest that there may also have been a supply response. For example, national-brand manufacturers may have lowered the effective price of national-brand products relative to private-label products. Similarly, retailers that experienced an increase in the demand for private-label products may have increased private-

label prices. Other supply responses such as the introduction of new private-label products and/or changes in the quality of private-label products are also a possibility.

The goal of this paper is to provide causal, demand-based estimates of household-level income and wealth effects on private-label demand as well as to provide evidence on the supply response (if any) to the experience of the Great Recession. To achieve this goal we utilize household-level transaction data for a comprehensive set of private-label and national-brand products as well as information on the supply side based on store-level scanner data. We use household data from the Nielsen Homescan panel to examine how income and wealth affect private-label demand. These data contain detailed purchase records of more than 130,000 households' CPG shopping histories across all U.S. retailers in more than one thousand food and non-food product categories. The data include 
demographic information including income and employment status. We supplement the Homescan data with two other data sources. First, we capture wealth using Zillow home value indices that are available at the local ZIP code level. Second, we use Nielsen's Retail Measurement System (RMS) database to measure the private-label and national-brand price levels that households face.

Our data cover the years 2004-2012, which include substantial data prior to and after the Great Recession. No other recession since World War II experienced as large a decline in real GDP and increase in unemployment as the Great Recession. ${ }^{1}$ The Great Recession is also the macroeconomic event associated with a largest impact on income and wealth since high-quality household panel data and store-level scanner data have been available. Our empirical strategy relies on two crucial features of the Great Recession. First, there were large changes in income and wealth over a short time horizon. Second, these income and wealth changes varied considerably across geographic areas and households.

The first major goal of our analysis is to establish a causal effect of income and wealth on private-label spending. We find that the aggregate private-label share increased by approximately one percentage point during the Great Recession. However, much of this increase appears to be part of a long-term trend that pre and post-dates the Great Recession. Even a deviation from this trend or a level shift in the private-label share need not indicate a causal effect, but could represent a change in private-label spending that would have occurred irrespective of the incidence of the Great Recession. Therefore, relying purely on the time-series variation in the data we cannot establish causal income and wealth effects without making strong assumptions about the counter-factual private-label spending patterns in the absence of the Great Recession. Similarly, the estimated income and wealth effects obtained purely from the cross-sectional (between) variation in private-label spending across households need not be causal. A selection bias would arise if, for example, households who choose careers with relatively high incomes also have systematically stronger preferences for branded products than households who choose careers with low incomes.

To establish causality, we exploit the panel structure of our data. We analyze the withinhousehold variation in private-label shares associated with within-household changes in income and wealth, controlling for other factors including an overall trend in private-label shares. The main identifying assumption is that conditional on all other controls, including an overall trend, withinhousehold changes in income and wealth are as good as randomly assigned or exogenous. The identifying assumption would be violated, for instance, if during the recession income and wealth systematically decreased for those households or in those areas with a systematically above average private-label share trend. However, we find no systematic evidence of a local (or household-specific) correlation between the pre-recession trend in private-label shares and the change in income, wealth, and unemployment during the recession.

We estimate a negative effect of income and wealth on household-level private-label shares, which is consistent with industry views and some prior academic work. However, the effect sizes are one

\footnotetext{
${ }^{1}$ Unemployment reached a slightly higher level in the 1981/1982 recession, but the increase in unemployment was smaller than during the Great Recession.
} 
or two orders of magnitude smaller than the estimates in some of the prior academic work once we control for persistent household differences and time trends. In contrast to these small effect sizes, the overall trend in the private-label share is large and increased during the recession.

The estimated income and wealth effects can be interpreted as causal subject to the identifying assumption stated above. However, in general these causal estimates will capture different mechanisms by which private-label demand was affected. First, income and wealth have a direct effect on private-label purchasing behavior as predicted by the theory of consumer demand. Second, income and wealth changes may affect the supply side, in particular the retail prices of national-brand and private-label products, creating an indirect effect on private-label demand. The second major goal of our analysis is to distinguish between these direct and indirect effects of income and wealth.

We estimate a demand model, allowing us to test if private-label products are inferior goods, which is not possible based on a private-label-share model only. We assume a demand model based on multi-stage budgeting across product groups. In the upper-level stage, households allocate their budgets across different products groups, including CPG (consumer packaged goods), the group that contains the products in our analysis. In the lower-level stage, households allocate the CPG budget across private-label and national-brand products. We model lower-level demand using an AIDS specification with household-level private-label shares as the dependent variable along with controls for private-label and national-brand prices and the overall price levels of the different upper-level product groups.

To estimate the demand model we construct private-label and national-brand price indices that are customized to each household's expenditure patterns across categories using the RMS scanner data. We find that changes in the national-brand/private-label price ratio that households face are correlated with household-level changes in income and wealth. Hence, the demand estimates could be subject to omitted variables bias if we did not include price controls. The correlation between the price ratios and income and wealth is not perfect, however, and hence disentangling the direct income and wealth effects on private-label demand from the indirect effect of income and wealth through their effect on prices is possible.

Our demand estimates, which control for private-label and national-brand price levels, show a negative direct income effect on private-label shares. Hence, the negative causal income effect in our initial analysis is robust to controls for prices. The estimated wealth effect is negative but not statistically different from zero.

To test if private-label products are inferior goods we predict the (total) income elasticity of private-label demand based on the elasticities of the private-label share and CPG spending with respect to income. We find that the point estimate of the income elasticity of private-label demand is positive. A 95 percent confidence interval includes negative and positive values, hence we can neither rule out that the private-label product group is an inferior good nor a normal good. In either case, the confidence interval indicates that the income elasticity of private-label demand is small.

Our findings of small income and wealth effects on private-label demand are in stark contrast 
to some prior academic work. In contrast to these small effect sizes, our household-level estimates reveal an economically large positive trend in the private-label share of .45 share points per year.

On the supply side, we find no evidence of a reduction in the relative price of national-brand versus private-label products either during the recession or after. The national brand/private label ratio remained constant during the recession and increased slightly afterwards. We also investigate whether the private-label share trends differ by quality tiers, defined based on private label/nationalbrand price ratios. Both academic researchers (ter Braak, Geyskens, and Dekimpe 2014) and industry practitioners have called attention to the growth in high-quality private-label products. However, our analysis does not reveal a stronger demand trend among higher-quality private-label products compared to lower-quality private-label products. We also examine new private-label and national-brand product introductions to see if these coincide with the strong demand trend and find that private-label and national-brand product introductions are remarkably stable during the sample period from 2006-2010.

The plan of the paper is as follows. After describing our household panel sample, we provide some descriptive analysis to document the extent of aggregate trends in private-label shares in Section 4. We argue that this aggregate analysis cannot provide causal estimates of the impact of income or wealth changes on private-label demand without strong assumptions on the counter-factual share outcomes. For this reason, we base our analysis on household-level data in Section 5. To construct estimates of the income effect on the demand for private label, we must construct a valid demand system and estimate this system using prices of national brand, private label and other products. Section 6 provides such estimates. Finally, we investigate various possible supply-side explanations for private-label-share growth in Section 7.

\section{Literature}

While academics have documented suggestive evidence that economic recessions are associated with private-label-share growth (e.g. Quelch and Harding 1996; Ang, Leong, and Kotler 2000), there are surprisingly few academic studies that rigorously test for income and wealth effects in private-label demand. Hoch and Banerji (1993) were among the first to draw attention to a "strong" negative correlation between disposable income and the private-label share using annual time-series data from the U.S. ${ }^{2}$ Lamey, Deleersnyder, Dekimpe, and Steenkamp (2007) find a similar countercyclical pattern between GDP growth and private-label demand using time-series analysis of national, annual private-label shares for four different countries. They conclude that "...the aggregate business cycle contributes to long-term private-label success." In a meta-analysis of annual U.S. time-series data for 106 CPG categories, Lamey, Deleersnyder, Dekimpe, and Steenkamp (2012) reconfirm that the private-label share is countercyclical. They also find that some of the cyclicality is moderated by a supply-side response, especially the pro-cyclicality of national-brand price promotions. They also estimate that for each 1 per cent decline in real per capita GDP, there will be a "permanent" increase

\footnotetext{
${ }^{2}$ See Figure 1, p. 59.
} 
in the annual growth rate of private-label expenditure share of 1.22 points (p. 9). In the most recent "Great Recession," real GDP per capita declined by 5.5\%. This means that the Lamey model would predict a permanent increase of 6.71 share points per year in private-label growth. This would more than double private-label share every 15 years and represents the largest documented effect of income on private-label share.

A related literature has used purely cross-sectional variation in household characteristics to study the sources of heterogeneity in tastes for private label. Most of this literature uses survey data (e.g. Murphy and Laczniak, 1979; Rosen, 1984; Batra and Sinha, 2000; Ailawadi, Neslin, and Gedenk, 2001). Studies using consumer purchase panel data also typically rely on cross-sectional variation in household characteristics (e.g. Erdem, Zhao, and Valenzuela, 2004; Hansen, Singh, and Chintagunta, 2006; Ailawadi, Pauwels, and Steenkamp, 2008; Bronnenberg, Dube, Gentzkow, and Shapiro, 2014). ${ }^{3}$ The evidence in these studies is mixed. Cross-sectional differences across consumers may not provide a reliable source of variation to test for income effects because of selection. Testing for selection bias is difficult and suitable instruments are not immediately obvious.

We contribute to this literature by using household-level panel data. The sample period includes several years pre-, during- and post-Great-Recession. We exploit geographic differences in the magnitude of the income and wealth shocks of the Great Recession to identify a causal effect of income and wealth on the private-label share.

Nevo and Wong (2014) use a subset of our household panel data to study the effects of the Great Recession on overall household grocery shopping behavior. They find a large increase in privatelabel share for CPG food categories during the recession. We use a longer time frame spanning 2004 to 2010, revealing a large trend in the private-label share that pre-dates the recession and explains much of the increase in the private-label share during the recession. We also conduct an extensive analysis of store-level price data for a large number of U.S. supermarkets. We find that the national-brand/private-label price ratio increased slightly during the recession, which would imply an increase in the returns to shopping for private-label products, in contrast with the findings in Nevo and Wong (2014).

In another related paper, Stroebel and Vavra (2014) use the same household panel data matched with retail prices in some product categories and local home values. They estimate a surprisingly large elasticity of retail prices with respect to local home values. They attribute this relationship to changes in mark-ups as opposed to changes in marginal costs. They also find that rising home values are correlated with lower private-label expenditure shares for home owners and increased private-label expenditure shares for renters. However, they do not control for retail prices in the regression and hence one cannot interpret these estimates as wealth effects on demand. In our analysis, when we control for local retail price levels, we estimate a negative wealth effect that is small and statistically insignificant. We also find that while higher home values lead to a lower private-label share in CPG expenditures, they also lead to a higher overall CPG expenditure level

\footnotetext{
${ }^{3}$ Some authors have used aggregate sales and market share data correlated with regional differences in demographics (Hoch and Banerji 1993; Raju, Seethuraman, and Dhar 1995; Dhar and Hoch 1997)
} 
and correspondingly a positive although statistically insignificant income elasticity of private-label demand. Therefore, in spite of the negative effect on private-label expenditure shares, we cannot reject that the private-label product group is a normal good.

Our work is also related to the broader literature studying consumer demand for CPG products over the business cycle (e.g. Gordon, Goldfarb, and Li (2013); Heerde, Gijsenberg, Dekimpe, and Steenkamp (2013); Kamakura and Du (2012); Estelami, Lehmann, and Holden (2001)). Unlike previous work, we have access to a much more comprehensive scope of product categories spanning all of the CPG industry.

\section{Data}

Our primary source of data is the Nielsen Homescan household panel. This panel provides us with information on shopping trips and items purchased in these trips for a large number of households over a period of time that extends before and after the Great Recession. To control for prices we use information from the Nielsen RMS (Retail Measurement Services) scanner data set. To measure housing wealth we use data from Zillow Inc. on housing values by ZIP code and month. In some of our analysis we also employ U.S. Bureau of Labor Statistics unemployment data that is available by county and by month. Below we discuss each data source in detail and provide information on how we cleaned and assembled the data.

\subsection{The Nielsen Homescan Panel}

The Nielsen Homescan data is available to academic researchers through a partnership between the Nielsen Company and the James M. Kilts Center for Marketing at the University of Chicago Booth School of Business. ${ }^{4}$ The raw data include the purchase decisions of 132,326 households who make over 500 million purchases during more than 88 million shopping trips between 2004 and 2012. To collect these data, Nielsen instructs households to use an optical scanner in their homes to scan the barcodes of each of the UPC-coded CPG (consumer packaged goods) items that they purchase during trips to supermarkets, convenience stores, mass merchandisers, club stores and drug stores. Details on the stratified sampling methodology employed by Nielsen to promote representativeness of the Homescan panel can be found in Kilts Center for Marketing (2013). A key advantage of the Homescan panel data set is that it includes all US retailers including mass merchants such as Walmart who do not offer their data for syndication.

For each purchased product we observe the date, the Universal Product Code (UPC), the price paid, an identifier for the chain in which the purchase was made, and several attributes of the product itself including brand name and pack size. The purchases cover over 3,198,950 unique UPC's ${ }^{5}$ from 1301 Nielsen product modules that represent the different product categories across

\footnotetext{
${ }^{4}$ http://research.chicagobooth.edu/nielsen/

${ }^{5}$ UPC's are unique to a specific product at any given moment in time but can be re-assigned to different products over time. Hence, the Kilts Center created a UPC version identifier for each product based on four "core" product attributes, product module code, brand code, multi-pack size, and pack size (volume). Combining the UPC and
} 
departments: Health and Beauty, Dry Grocery, Frozen Food, Dairy, Deli, Meat, Fresh Produce, Non-Food, Alcoholic Beverages and General Merchandise. Using the 2009 Consumer Expenditure Survey, we estimate that the Homescan products represent approximately one quarter of the average annual household expenditures. ${ }^{6}$

When analyzing private-label spending, we drop all the modules from the General Merchandise, and Alcoholic Beverages departments. These modules contain products that are frequently purchased in store formats that are not tracked in the Nielsen RMS data, for example printer cartridges and automotive motor oil. Moreover, many of these modules have limited or no private-label offerings.

We used several procedures to filter out some households who did not remain in the panel for a reasonable length of time or appeared inconsistent in their purchase records. Specifically, we applied the following filters to the raw household data:

(i) Each panelist must be in the data for at least six months.

(ii) Each panelist must average at least three trips per month.

(iii) A panelist may not have a gap of six months or more in their purchase records.

We also removed a very small number of transactions with unusually large or small prices. Specifically, we filtered out any transaction whose recorded purchase price for a specific product was more than four times the median price or less than one fourth of the median of all transactions (across all households) for that product. We also removed any products purchased less than twenty-five times in the whole data set. Finally, we only retained those product modules present in all years in the Homescan data. Table 1 summarizes the number of panelists, number of trips, number of transactions, and the total expenditure across all Homescan households by year. We show both the summary statistics for the whole data set, indicated as "Raw," and the summary statistics for the data obtained after applying the filters. When applying the filters we retain 86 percent of all households and 85 percent of all expenditures.

The data also contain annual survey information for all Homescan households. The survey provides self-reported information on demographic characteristics such as income, education, race, and age of the household heads. The survey also reports information about household composition, home ownership, and where the households live. The raw Homescan data are not representative of the U.S. population at large. Therefore, Nielsen provides sampling weights (projection factors) that can be used to make the raw sample representative of the populations in the whole U.S. and in 61 geographies along nine demographic variables. ${ }^{7}$ In Table 2, we compare the raw (unweighted) marginal distributions of age, education and income from the 2011 Homescan survey to the 2010

version identifiers we can uniquely identify each product in the data over time.

${ }^{6}$ In the 2009 CEX data, the categories "food at home," "alcoholic beverages," "personal care products and services," and "tobacco products and smoking supplies" which are closest to those measured in the Homescan panel have total CEX spending of $\$ 5,164,000$. Overall CEX spending is $\$ 19,043,000$.

${ }^{7}$ The variables are household size, income, age of head of household, race, Hispanic origin, education of male and female household heads, occupation of head of household, presence of children, and Nielsen county size. 
Census. Compared to the Census data our sample is slightly older, somewhat more educated, and the income distribution is attenuated in both tails. However, there is a substantial overlap in the distributions of the demographic variables between our sample and the Census data. In the key parts of our empirical analysis, we employ regression methods that control for household demographic factors. As long as the Homescan and Census distributions of these demographics variables overlap, our regression methods will not require any adjustment to the data to reflect concerns of lack of representativeness in demographics. In other parts of the empirical analysis, where we analyze aggregate private-label expenditure shares, we use the sampling weights provided by Nielsen to make the predictions representative at the national level.

We will employ an estimation strategy that relies on within-household income variation over time to estimate the causal effect of income on private-label demand. Measuring the exact timing of income changes is hence crucial. Nielsen conducts the household surveys during the fall of year $t-1$ preceding the "panel year" $t$ when the obtained demographic information is reported in the data. In particular, at the time of the survey Nielsen asks the households to report their annual income in the previous year, i.e. year $t-2$. Therefore, for each household we match the income in panel year $t$ to the transaction data in year $t-2$. In the parts of the analysis that rely on both purchase and income data, we can only employ observations for households who were in the Homescan panel for at least three years. The corresponding number of matched observations is reported in Table 1, indicated as "Income-Matched." We retain 71 percent of all households and 62 percent of the expenditures in the raw data. In the parts of the analysis that rely only on purchase but not income data we use all (filtered) observations.

\subsection{The Nielsen RMS (Retail Measurement Services) data}

The Kilts Center for Marketing also provided us with access to Nielsen's RMS (Retail Measurement Services) scanner data. These data contain store-level unit sales and price data by UPC and week for approximately 35,000 stores in over 100 retail chains from 2006-2011. The Kilts Center data include the subset of stores belonging to retail chains that authorized Nielsen to release their data for academic research purposes. Among these chains every major format is represented, including grocery, drug, convenience, and mass merchant stores. However, the RMS sample is not a census. For example, the largest U.S. retailer, Walmart, is not included in the RMS data.

\subsection{Household wealth data}

One of the most striking effects of the Great Recession was the steep decline in home values. Iacoviello (2011) estimates that about one half of all U.S. household wealth is held in the form of real estate. Thus, the Great Recession provides an ideal opportunity to study the effects of large wealth changes on the demand for private-label products. We use Zillow Inc.'s Home Value Index to measure home values by ZIP code. The Zillow home value index is computed using Zillow's "Zestimate," an estimate of the market value of a property. Zillow uses a proprietary formula and different data sources to compute this estimate. The data sources include property appraisals, 
location, market condition, and transaction data for properties in the same geographic area. The description ${ }^{8}$ provided on Zillow.com suggests a hedonic approach whereby properties are represented in terms of attributes and the local value of each attribute is computed from transaction data. The local value of each attribute is then used to compute the total local value of a property. The Zillow home value index is the median of the Zestimates available for properties in a given ZIP code. ${ }^{9}$ To obtain a household-level measure of housing wealth we match the home value indices to the Homescan households at the ZIP code level.

Zillow data have been used in the finance literature to study the links between the real and financial sectors of the economy (Mian, Sufi, and Trebbi 2011) and in economics to study the dynamics of city growth (Guerrieri, Hartley, and Hurst 2010). The Zillow data cover many of the most populated ZIP codes in the U.S., but do not provide complete coverage of the entire country. Zillow coverage rates ${ }^{10}$ are above 80 percent in many U.S. states; but some important states, notably Texas, have no coverage. Generally speaking, Zillow coverage is best in those states which have the highest housing values (e.g California where the coverage exceeds 95 percent). In more rural states and states with lower housing values, the coverage of the Zillow index is often below 50 percent. The household-months in the Homescan data that we can match to a Zillow index account for about 64 percent of all expenditures in the data.

The Zillow home value indices illustrate both the severity of the Great Recession as well as its disparate impact by region. The map in Figure 1 shows the distribution of home values in 2006 and 2009. The recession had a particularly large impact on home values in the Southwest and in Florida. The figure also shows the coverage issues with respect to the Zillow index: All ZIP codes with a missing Zillow value are colored white.

\subsection{Comparison of private-label expenditure shares in the Nielsen Homescan and RMS data}

As discussed above in Section 3.1, the Homescan sample is approximately representative of all U.S. households in some key demographic attributes when the sampling weights (projection factors) supplied by Nielsen are applied. However, this does not necessarily rule out that there are systematic differences between the Homescan panel and the US population in the preferences for private-label products. To examine if there are systematic differences in private-label demand across the two data sources we identify three of the seven largest retailers, based on Homescan expenditures, that are also represented in the RMS data. Figure 2 displays the time series of aggregate private-label expenditure shares at these three chains, calculated using both the Homescan and the RMS data. There is a small difference in the levels (the shares predicted using the RMS data are slightly larger), but the Homescan and RMS private-label shares move closely together (correlation $=0.956$ ). This evidence suggests that the Homescan purchase records are largely representative of the population

\footnotetext{
${ }^{8}$ http://www.zillow.com/wikipages/What-is-a-Zestimate/

${ }^{9}$ http://www.zillow.com/wikipages/What\%27s-the-Zillow-Home-Value-Index/

${ }^{10}$ We define coverage as the percentage of the total housing units in a region that have non-missing Zillow housing value estimates.
} 
at large, at least with regard to private-label purchase patterns.

\section{Descriptive analysis}

\subsection{The basics: Private-label shares and relative prices}

Most of our empirical analysis focuses on private-label expenditure shares as a measure of privatelabel demand. For each household $h$ and period (month) $t$ we observe total spending on consumer packaged goods products $(\mathrm{CPG}), y_{C P G, h t}$, and spending on private-label products, $y_{P L, h t}$. The private-label share is then defined as $s_{h t}=y_{P L, h t} / y_{C P G, h t}$. Recall from Section 3.1 that we calculate the private-label shares using purchases in all departments with the exception of the General Merchandise and Alcoholic Beverages departments. Table 3 summarizes the cross-sectional distribution of private-label shares across household-years. The mean private-label share (weighted using the projection factors) is 19.5 in all departments and 20.66 for food products only. The private-label shares exhibit much heterogeneity across household-years. For example, 90 percent of all observations are in the range from 9.09 to 73.12 percentage points.

The data include both food and non-food products unlike some previous work that uses only food products (e.g. Nevo and Wong (2014)). Private-label products are very important in many non-food categories. Six of the top twenty product categories, ranked by total private-label expenditure, are non-food products, including Nutritional Supplements (rank 5), Toilet Tissue (8), Cold Remedies (10), Headache/Pain Remedies (11), Paper Towels (16), and Dog Food (19).

Private-label products offer consumers a substantial price discount relative to national-brand products. Based on the transaction prices in the Homescan data, the expenditure-weighted average private label/national-brand price ratio is 0.70 across all years. ${ }^{11}$

\subsection{Private-label-share evolution}

The top panel of Figure 3 displays the evolution of the monthly aggregate private-label share from 2004 to 2012. The included trend curve is estimated using the non-parametric LOWESS (locally weighted scatterplot smoothing) estimator. The recession period (December 2007 - June 2009 based on the NBER's business cycle dating procedure) is shaded in gray. Private-label share only increased by about one per cent during the recession period. An examination of the whole sample period from 2004 until 2012, however, reveals that this increase is part of an overall positive trend by which the private-label share increased by about 0.45 points per year.

The smaller panels at the bottom of Figure 3 show the relationship between the aggregate private-label share and some important macro-economic variables, real GDP ${ }^{12}$ in trillions of 2009 dollars, unemployment, and the Consumer Confidence Index. Focusing only on the recession years

\footnotetext{
${ }^{11}$ We first calculate the ratio of expenditure-weighted prices per equivalent unit in all groups of products that belong to the same category and for which volume is measured in the same equivalent units. We then take an expenditure-weighted average over these group price ratios.

${ }^{12}$ Obtained from Macroeconomic Advisors, http://www.macroadvisers.com/monthly-gdp/
} 
we find a strong correlation between the private-label shares and the macro-economic factors, indicating an increase in private-label demand that is associated with adverse economic conditions. However, no such correlation is present over the whole sample period (regressions of the private-label share on the economic variables yield estimates that are not statistically different from zero).

This brings us to the key question in this paper: Do adverse economic conditions have a causal effect on private-label demand? Let us ignore for now that we are not controlling for other factors that are likely to affect private-label demand, such as private-label and national-brand price levels (we will control for these factors in our empirical analysis below). The top panel in Figure 3 suggests that the increase in the private-label share during the Great Recession was unusually large relative to the overall trend. We could use this trend-deviation as evidence for a causal effect of the recession on private-label demand. Any empirical analysis that relies purely on time-series variation needs to draw inferences about causal effects from such trend-deviations. This approach relies on some very specific assumptions about the counter-factual or potential private-label share that would have been observed in the absence of a recession. In particular, we need to have a strong prior on the shape of the trend and we need to assume that any deviations from this trend are necessarily due to the causal factors, income and wealth, in which we are are interested. Both are strong assumptions. Our approach, outlined in detail below, follows a different route and relies on crosssectional differences in the income and wealth shocks experienced by the households to establish causality. This identification strategy does not rely on any specific assumptions on the aggregate trend in the private-label share.

\section{The causal relationship between income, wealth, and the private- label expenditure share}

\subsection{Empirical strategy}

We estimate the relationship between income, wealth, and private-label demand using the following regression:

$$
s_{h t}=\beta_{0}+\beta_{1} \log \left(I_{h t}\right)+\beta_{2} \log \left(W_{h t}\right)+\beta_{3}^{T} \phi(t)+\beta_{4}^{T} x_{h t}+\epsilon_{h t} .
$$

$s_{h t}$ is the private-label share of household $h$ in month $t$, and $I_{h t}$ is the income of household $h$. We proxy for household wealth $W_{h t}$ using the local Zillow home value index, measured at the ZIP code level. $\phi(t)$ is a vector-valued function of the time period $t$ that captures time dummies and trends, and $x_{h t}$ is a vector of other covariates including household demographics.

Estimates of the income and wealth coefficients in equation (1) need not represent causal effects, as is always the case in observational studies. Since an experimental manipulation of household income and wealth is not feasible, we need to be clear about the source of the variation in the observed, non-experimentally generated income and wealth levels that allows us to establish causal effects. In particular, the cross-sectional differences in income and wealth across households need not be a reliable source of variation because of selection: households with high incomes may have 
systematically different preferences for private label versus national brands than household with low incomes. For example, households might differ in the importance that they attach to status and prestige. Those households who are driven by status may choose careers associated with high incomes and may also have a strong preference for branded products. In this case, higher incomes will be associated with a smaller private-label share, $\beta_{1}<0$, even though the statistical relationship does not represent a causal effect of income on private-label demand.

The selection concerns can be resolved using household fixed effects in (1) that control for for persistent differences in private-label demand across households. The income and wealth coefficients are then estimated using the within-household variation in income and wealth over time. To establish causality we rely on the large variation in income and wealth due to the severity and diverse geographic impact of the Great Recession. Figure 4 shows the large geograhic differences in the impact of the Great Recession using with a map of unemployment at the FIPS county level in 2006 and 2009. Similarly, Figure 1 shows a corresponding map of Zillow home value indices at the ZIP code level. Figure 5 shows histograms of the cross-sectional distribution of the differences in unemployment and (log) house values between January 2006 and December 2009. The plots indicate large regional differences in the changes in unemployment and home values. While unemployment fell in some regions, in others it increased by up to 15 percent. Similarly, home values increased in some regions, but dropped by more than 60 percent in others. This geographical variation in the magnitude of the recession effect on local economic conditions provides us with the main source of variation to interpret the estimated income and wealth effects in (1) as causal.

The main identifying assumption to establish causality is that conditional on all other controls, including the time trends in $\phi(t)$, within-household changes in income and wealth are as good as randomly assigned, a phrase frequently used in the recent literature on causality. A precise meaning of this phrase can be established using the Neyman-Rubin causal model (see Imbens and Rubin 2015 for a detailed exposition and references). Let $s_{h t}(i, w)$ be the potential private-label share given income level $i$ and wealth $w$. In the data we only observe the private-label share at the realized income and wealth of household $h, s_{h t}=s_{h t}\left(I_{h t}, W_{h t}\right)$. $X_{h t}$ is a vector of other covariates. Then the main identifying assumption, referred to as unconfoundedness in the treatment effects literature, is:

$$
s_{h t}(i, w) \Perp\left(I_{h t}, W_{h t}\right) \mid X_{h t}, h \quad \forall(i, w) .
$$

For example, this assumption rules out that households who would have increased their share of private-label spending irrespective of income and wealth systematically experienced an actual decrease in income and wealth. A priori, it seems unlikely that the effects of the Great Recession were particularly severe for those households with systematically above average positive trends in private-label spending.

The unconfoundedness assumption is not directly testable. However, we can provide some corroborating evidence that indirectly supports the assumption by examining (i) the relationship between household or regional trends in private-label spending before the recession and (ii) changes in income, unemployment, and wealth during the recession. For example, suppose that income 
and wealth systematically fell during the recession for households or for regions with a positive trend in private-label spending. If this trend pre-dated the recession, we would also find a negative correlation between the change in income (or wealth) during the recession and the change in privatelabel spending before the recession. We calculate differences in private-label shares between the two periods prior to the recession and differences in county-level unemployment, ZIP code housing values, and household income between two periods during the recession. The correlations are reported in Table 4. We provide results for several time slices. For example, we correlate the change in privatelabel shares between 2004 and 2006 and the change in unemployment between 2007 and 2009 . Similarly, we correlate the change in private-label shares between the first quarter of 2004 and the first quarter of 2007 and the corresponding change in unemployment between the second quarter of 2007 and the second quarter of 2009. We separately calculate the correlations for private-label share changes in all categories and changes in food categories only. All correlations are small, in most instances less than 0.03 in absolute value. We reject the null hypothesis of no correlation in four out of thirty correlations, but with corresponding p-values that are only marginally significant of between 0.033 and 0.049. All four statistically significant correlation coefficients are negative, which is consistent with the example of a violation of the identifying assumption (2) that we gave above. However, the number of instances where we reject the null hypothesis is small, and these instances are not consistent across small variations in how the time periods before and during the recession are defined. ${ }^{13}$

\subsection{Estimation results}

Table 5 reports several different specifications of the private-label share regression (1). All specifications include the log of household income and the log of Zillow home values in a household's ZIP code. We also include a household-level unemployment dummy that may capture unmeasured income components or permanent income components such as expectations of future income.

Column (1) contains results based on a specification that pools across all households, and column (2) contains the between-household estimates that are entirely based on the cross-sectional variation of all variables across households. In these two specifications we control for DMA fixed effects and household-specific effects using various demographic variables, including household composition, education, and ethnicity. In both specifications the income and (housing) wealth estimates are negative and statistically significant. The income estimate in the between specification implies that a 25 percent reduction in income increases the private-label share by 0.84 percentage points. Similarly, a 25 percent reduction in housing wealth increases the private-label share by 0.35 percentage points.

In column (3) we control for persistent household-specific factors using household fixed effects. In column (4) we add a dummy variable for all months during the Great Recession (December 2007 - June 2009 according to the NBER's business cycle dating procedure) and a dummy for the

\footnotetext{
${ }^{13}$ For example, the p-value for the correlation in the share difference between 2005 and 2006 and the difference in (log) housing values between 2007 and 2009 is 0.033, but the corresponding p-value if the share difference is calculated between 2004 and 2006 is 0.913 . We interpret the evidence as consistent with assumption (2), even though it is not a direct test.
} 
post-recession period. In column (5) we add an overall linear trend variable, and interactions of the trend with the recession and post-recession dummies. Specifically, for the recession period the trend interaction is defined as follows:

$$
\text { trend_recession } t=\mathbb{I}\left\{t_{0} \leq t \leq t_{1}\right\} \cdot\left(t-t_{0}+1\right) \text {. }
$$

Here $t_{0}$ and $t_{1}$ indicate the first and last recession month. Using this specification we can assess the trend in private-label shares during the recession by the sum of the overall trend and the trend/recession interaction. The trend interaction for the post-recession period is defined analogously, and we can assess the trend in the periods after the recession by the sum of the overall trend and the trend/post-recession interaction. The within-household estimates of the income, wealth, and unemployment effects in columns (3)-(5) are substantially different from the pooled and between-household estimates. Also, the recession and post-recession dummies as well as the trend variables are all statistically significant. We hence focus on the estimates in column (5). Controlling for household fixed effects, the income effect and, to a lesser degree, the wealth effect are substantially smaller than the pooled and between-household estimates. The estimates imply a 0.12 percentage point increase in the private-label share for a 25 percent reduction in income, and a 0.16 percentage point private-label share increase for a 25 percent drop in the home value. Being unemployed increases the private-label share by 0.37 points, holding income constant. In reality, unemployment is associated with a large drop in income. For example, if the unemployed household retains 40 percent of her pre-unemployment income in transfer payments then the private-label share increases by 0.75 points.

Controlling for all other factors, including the trend variables, the overall private-label share was higher during the recession (0.32 percentage points) and also after the recession ( 0.48 percentage points). The overall trend estimate is 0.0372 , implying an annual 0.45 percentage point increase in the private-label share. The level shift due to the recession, 0.32 points, is equivalent to about nine months of the trend effect. Our estimates also indicate a significant decline in the trend during the post-recession period. However, we hesitate to put much emphasis on this decline because of the limited number of sample periods in the post-recession period. In particular, the last sample year used to obtain the results is 2010 (recall from our discussion in Section 3.1 that the income data matched to transactions in 2010 are reported in the 2012 Homescan data, the last year currently provided by the Kilts Center). ${ }^{14}$

In Appendix B, we report analogous estimation results for the more homogenous group of food products only. The estimates for food products are comparable to the estimates based on all categories.

The within-household estimates indicate a negative effect of income and wealth on private-label demand. If within-household changes in income and wealth are as good as randomly assigned, then these effects are causal. However, while the estimates have the expected sign, the economic signif-

\footnotetext{
${ }^{14}$ We expect to be able to obtain data for 2013 in a future revision of this paper.
} 
icance of the estimates is small. In contrast, the overall trend is large, implying a 4.45 percentage point increase in the private-label share over a decade.

\subsection{Supply response, measurement error and permanent income concerns}

The estimation results presented above are subject to some limitations that we will resolve in the next section. First, we will provide conditions under which the regression (1) can be interpreted as part of a valid consumer demand model. Second (and related to the first point), the potential private-label shares realized for a given household may be affected by income and wealth changes experienced by other households. In particular, local income and wealth changes may cause a supplyside response whereby the prices of private-label products versus national brands are affected. If such a price response occurred the SUTVA (stable unit treatment value assumption) would be violated (see Imbens and Rubin 2015 for a discussion) and interpreting the income and wealth estimates as causal would no longer be straightforward. We will address this issue in the next section.

We found that the within-household estimates of the income and wealth effects are significantly smaller than the pooled or between-estimates. This may indicate selection effects, whereby high income households have different preferences for private-label versus branded-products than lowincome households. One alternative explanation is that the inclusion of household fixed effects potentially increases the attenuation bias due to measurement error. Another possible explanation for the differences between the results which use cross-sectional variation and the results which use within variation is that the income variation we see in the "within" results represents primarily transient shocks to income, while the cross-sectional variation in income reflects more of the variation in permanent income between households. We address these concerns below in Section 6.4.

\section{$6 \quad$ Estimating income and wealth effects on private-label demand}

\subsection{Demand model}

In the previous section, we showed that there is an effect of income and wealth on the private-label share in spending. These estimated effects are causal subject to our identifying assumptions, and allow us to measure the effects of income and wealth on private-label purchasing behavior without imposing a specific model of consumer demand. However, the exact mechanism through which income and wealth affect private-label demand is not clear from this analysis. First, the theory of consumer demand predicts that in general, income and wealth have a direct effect on privatelabel purchasing behavior. Second, income and wealth changes may affect the supply-side behavior of manufacturers and retailers, in particular the retail prices of national-brand and private-label products. Thus, income and wealth may have an indirect effect on private-label demand through its impact on relative prices. In this section, we separate these direct and indirect effects of income and wealth using a proper consumer demand model. Based on a demand model we can also test whether private-label products are normal or inferior goods. 
Ideally, we would fit one of the many flexible consumer demand models that have been developed in the marketing literature to the data, such as a mixed discrete-continuous demand model as in Kim, Allenby, and Rossi (2002). In practice, we would have to estimate such a demand model for all 953 product categories in our data, which is beyond the capabilities of the current state of estimation of these models. Instead, we simplify the analysis by modeling a demand system with multi-stage budgeting across commodity groups, an approach that has been used previously in the consumer demand literature (e.g. Hausman, Leonard, and Zona 1994). The model that we propose is consistent with utility maximization under specific conditions on preferences. We use a two-stage model of demand derived from Gorman's two-stage budgeting framework (see Deaton and Muellbauer 1980b for a general discussion). At the upper level of demand, households allocate their total income across different commodity groups. One of these commodity groups includes the consumer packaged goods (CPG) in our data. At the lower level of the demand, households allocate the CPG budget across national-brand and private-label products.

We emphasize that the analysis in this section is not a substitute or replacement for the analysis in Section 5. In Section 5 we provided evidence for causal income and wealth effects on privatelabel shares without imposing any assumptions on consumer demand. In this section we distinguish between direct and indirect income and wealth effects on private-label demand subject to the specific assumptions in the estimated demand model.

\section{Upper level demand}

At the upper level of the demand model households allocate their budget across $K$ product groups. Our upper level demand groups are defined as all CPG goods, General Merchandise items, and all other non-durable goods captured in regional CPI. We focus on the CPG group and model the total expenditure on the CPG group, $y_{C P G}$, as follows:

$$
\log \left(y_{C P G}\right)=\eta+\delta_{I} \log (I)+\delta_{W} \log (W)+\sum_{k=1}^{K} \tilde{\alpha}_{k} \log \left(P_{k}\right)+\nu .
$$

For notational simplicity, we drop the household and time subscripts in this section. $P_{k}$ is the

price index for commodity group $k$. Correspondingly, $Q_{C P G}=y_{C P G} / P_{C P G}$ is a quantity index for the CPG product group. The error term $\nu$ captures unobserved determinants of the total CPG expenditure. We model upper-level demand for CPG in a manner similar to other research (e.g. Hausman, Leonard, and Zona 1994). Unlike past work, we also include controls for prices in other non-CPG commodity groups.

\section{Lower level demand}

At the lower level of demand, we assume PIGLOG preferences over the national-brand and privatelabel product groups. Under this assumption we obtain the "Almost Ideal Demand System (AIDS) 
of Deaton and Muellbauer 1980a with the following private-label expenditure share equation:

$$
\begin{aligned}
s & =\frac{P_{P L} Q_{P L}}{P_{P L} Q_{P L}+P_{N B} Q_{N B}} \\
& =\tilde{\beta}+\tilde{\gamma} \log \left(\frac{y_{C P G}}{P_{C P G}}\right)+\lambda_{P L} \log \left(P_{P L}\right)+\lambda_{N B} \log \left(P_{N B}\right)+\tilde{\epsilon} .
\end{aligned}
$$

Here, $P_{P L}$ and $P_{N B}$ are price indices for the private-label and national-brand product groups. Substituting the upper level expenditure model (3) into the share equation (4) we obtain the following specification:

$$
s_{P L}=\beta+\gamma_{I} \log (I)+\gamma_{W} \log (W)+\lambda_{P L} \log \left(P_{P L}\right)+\lambda_{N B} \log \left(P_{N B}\right)+\sum_{k=1}^{K} \alpha_{k} \log \left(P_{k}\right)+\epsilon
$$

This share equation is a generalization of the private-label share regression (1) in Section 5. Unlike (1) it controls for product prices and can be interpreted as a proper demand model.

A priori we expect that the assumptions behind the upper level demand system are largely innocuous. However, the lower level demand system imposes some stringent restrictions on the substitution patterns between products. In particular, the relative price of a national brand versus the price of a private-label product in a specific product category affects substitution only through its effect on the overall national-brand and private-label price indices.

\subsection{Analysis of national-brand/private-label price evolution}

A concern with the analysis in section 5 is that a re-adjustment of retail prices, on the supply side, could confound any findings of a recession effect. Industry opinions about supply-side price adjustments in the CPG industry during the recession have been mixed. A USDA report attributes privatelabel-share growth to a "2007-2008 food price spike and 2007-2009 recession," finding national-brand promotional activity to be flat during the recession ${ }^{15}$. In contrast, a Nielsen report found that "Since the end of 2008, private brand share growth has flattened as brands stepped up their promotion support and innovation efforts." 16 In this section, we document the evolution of national-brand and private-label prices during our sample period. Appendix A describes the procedure used to construct the national-brand and private-label price indices.

Table 6 shows the average regional (DMA) national-brand/private-label price ratio by year. These indices are obtained using regional expenditure weights instead of household-level expenditure weights in formula (12). We find that national-brand prices increased relative to private-label prices by about 2 percent in 2009 and stayed at this higher level until the end of the sample period, 2011. Figure 6 shows the distribution of yearly percentage changes in the price ratios $\left(\log \left(P_{N B, t} / P_{P L, t}\right)-\log \left(P_{N B, t-1} / P_{P L, t-1}\right)\right)$ across regions. The graph documents some regional variation in the evolution of national-brand-to-private-label price ratios.

\footnotetext{
${ }^{15}$ http://www.ers.usda.gov/media/187072/err129_1_.pdf

${ }^{16}$ http://www.storebrandsdecisions.com/news/2012/02/07/nielsen-private-label-outlook-is-sunny
} 
We next investigate if the regional differences in the evolution of the price ratios are related to local economic factors. We match local (ZIP code) housing price indices and local (county) unemployment rates to each household, and then regress the log change in the national-brand-toprivate-label price ratios on the log change in household income, the log change in house values, and the difference in the local unemployment rates. We also control for year fixed effects. The results are in Table 7, shown separately for price indices based on regional category expenditure weights and household-level expenditure weights. There is clear evidence for a statistical relationship between the change in relative national-brand/private-label prices changes in the local economic conditions. Decreases in house values and increases in unemployment are associated with an increase in the price of national brands relative to private-label products. Income decreases are also associated with an increase in the national-brand relative to the private-label price; although the effect is statistically insignificant. The effects are moderated by the percentage change in the local CPG price index: a decline in the $\mathrm{CPG}$ price level is associated with an increase in the national-brand prices relative to the private-label prices. In sum, our evidence suggests that deteriorating macroeconomic conditions are associated with an increase in the national-brand prices relative to private-label prices.

There are two key implications of this analysis for the main goals of the paper. First, the results demonstrate the potential for omitted variables bias if we fail to control for relative price changes when estimating income and wealth effects on private-label demand. Second, even though there is a clear and overall statistically significant association between the price ratio changes and changes in the economic variables, the regressions do not explain all the variation in national-brand versus private-label prices (the $R^{2}$ numbers are about 0.43 for regional price indices and about 0.16 for household-level price indices). Consequently, we can still distinguish between a direct effect of income and wealth on private-label demand and an indirect effect through relative prices.

\subsection{Lower level demand (AIDS private-label share system) results}

We present the lower level demand estimates for the AIDS private-label share equation (5) in Table 8. Column (1) contains our preferred specification that we used to test for causal income and wealth effects in Section 5. This specification includes household fixed effects, recession and post-recession dummies, and trend variables. In column (2) we add the household-level price indices for nationalbrand and private-label products and a price index for the entire CPG product group. We find that the income and unemployment status effects decline slightly. The housing wealth effect becomes much smaller and is no longer statistically significant. We expected that the income, unemployment, and wealth estimates would change if we included the price variables in the regressions because of the correlation between changes in the economic variables and relative national-brand/private-label price levels that we documented above in Section 6.2. The recession and post-recession dummies also become substantially smaller, but the trend estimates are largely robust to the inclusion of the price controls. ${ }^{17}$ In column (3) we add the household-level price index for the "General Merchandise"

\footnotetext{
${ }^{17}$ As already discussed in Section 5.2, we hesitate to place much emphasis on the decline in the post-recession trend due to the short sample during the post-recession period.
} 
group and the regional CPI to proxy for the price level of all other products and services. The main estimates remain largely unchanged when we control for these additional price indices.

Therefore, the main findings from Section 5 are robust to the inclusion of price controls. The income and wealth effects have the expected signs, although only the income effect is precisely estimated whereas the wealth effect is no longer statistically significant once the price indices are added to the regression. However, the economic significance of the variables is small. A 25 percent decline in income implies a 0.11 percentage point increase in the private-label share, and a 25 percent drop in the home value implies a 0.05 percentage point increase. Being unemployed increases the privatelabel share by 0.35 points, holding all other factors constant. More realistically, unemployment and a corresponding 60 percent income decline lead to a 0.70 percentage point private-label share increase. In appendix B below, Table 16 provides the same regression specifications but with the different method of construction of the price indices. In the appendix table, we show that the use of fixed regional weights to construct the price indices instead of household-specific (but fixed over time) weights leads to similar results.

In our preferred specification (3), the national-brand price index estimate is positive but not statistically significant. The private-label price index is also positive and thus has the "wrong" sign. The estimate, however, is only marginally significant. Quantitatively, the price effects are very small. Among the product group price indices only the "General Merchandise" index is precisely estimated and also has the "correct" sign.

In Table 14 in appendix B, we present the analogous lower level demand estimates for the more homogenous group of food products only. Overall, the results are similar. However, the nationalbrand price effect is substantially larger (and statistically significant), whereas the private-label price effect is small and not statistically significant.

\subsection{Sensitivity analysis}

Our estimates show that household income has a precisely measured but economically small effect on the private-label expenditure share. We now explore if this effect size is small because of attenuation bias due to measurement error in income, or because we do not properly account for the effects of current versus permanent income.

\section{Measurement error in income}

Income is self-reported by the Homescan households. In particular, during fall of a given year the households respond to a survey and report their annual income for the prior year. We doubt that there is much measurement error in the level of income. However, our estimation strategy utilizes within-household changes in income, and such changes may be subject to larger degree of error in the reported income. Also, income is reported in one of twenty bins and hence there will be some round-off error.

To explore the sensitivity of our results to measurement error in income, we re-estimate the private-label expenditure share demand system using only observations for households that expe- 
rienced relatively large income changes in the sample period. In particular, we select households who experienced at least one $n$ percent income change in absolute value relative to the prior year. Table 9 displays our preferred specification of the AIDS private-label share system in column (1), and compares the estimates to specifications for households who experienced an income change of at least $n=10$ or $n=20$ percent in absolute value in columns (2) and (3). The estimated income effect decreases slightly (in absolute value) in specification (2) and by a modest amount in specification (3), from -0.38 to -0.293 . These results do not provide evidence for attenuation bias.

We also explore the extent of measurement error in income required to affect our conclusions about the income effect on private-label demand significantly. Let $I_{h t}$ be reported income, which is a noisy measure of the true household income, $I_{h t}^{*}: \log \left(I_{h t}\right)=\log \left(I_{h t}^{*}\right)+\omega_{h t}$. The measurement error in reported income, $\omega_{h t}$, leads to attenuation bias in the estimated income effect:

$$
\operatorname{plim} \hat{\delta}_{I}=\frac{1}{1+\frac{\sigma_{\omega}^{2}}{\sigma_{\log \left(I^{*}\right)}^{2}}} \delta_{I} .
$$

Here, $\sigma_{\omega}^{2} / \sigma_{\log \left(I^{*}\right)}^{2}$ is the noise-to-signal ratio, the variance of the measurement error relative to the variance of true income. We conduct the following thought experiment. Suppose we knew the noise-to-signal ratio. Then we could infer the true income effect from the estimated, biased income effect from equation (6), and correspondingly we could predict the true change in the private-label expenditure share for different changes in household income. In Table 11 we report the corresponding true income effects based on estimated income effects and small (0.5), medium (1), and large (10) values of the noise-to-signal ratio. For the "medium" degree of measurement error the true income effects would be twice as large as the measured effects, but the economic significance of the income effect would still be small. Only for the unrealistically "large" degree of measurement error with a noise-to-signal ratio of 10 would we find a substantially changed true income effect.

\section{Current versus permanent income}

Our identification strategy relies year to year "within" household variation in income. This variation in income can have both a permanent and a transient component. We might suspect that the within variation is driven more by short term shocks to income and hence our causal estimates may reflect more of the response to changes in transient as opposed permant income. In this section, we explore sensitivity of our income effect estimates to the distinction between permanent and current income.

Our estimated demand models contain a household-level unemployment indicator that may proxy for expectations about future income and hence capture permanent income effects. To further explore the difference between the effects of current and permanent income we introduce several additional measures that may capture permanent income components in the private-label share equation. The results are reported in Table 9. In column (4), we add an indicator for the year when the household became unemployed in addition to the unemployment indicator. The "became unemployed" estimate is small and not statistically different from zero. Hence, the evidence does 
not suggest that the effects of short term unemployment are different from the effects of long term unemployment. Older households may perceive income changes as more permanent than younger households. Correspondingly, in column (5) we add the interaction of income with the log age of the household head to the share equation. Also, unemployed households may perceive income changes as more permanent, and hence we add an interaction of log income and the unemployment indicator in column (6). Both estimated interactions are small and not statistically significant.

In Table 10 we examine the effect of lagged $(\log )$ income on the private-label share. We compare model specifications that include between one and four income lags. All four models with lags indicate that both current and past income levels affect private-label demand. The first income lag is mostly of equal or slightly larger magnitude than the contemporaneous income effect, whereas the higher-order lags are smaller. In the specification with four lags, the third lag is not statistically different than zero, but the fourth lag is statistically significant. We can match prices to the household-level purchases only for the years 2006-2011, and hence we cannot explore the effect of lags of order five or higher. However, the declining coefficient pattern in Table 10 suggests that four lags are likely to capture most of the past income effects. Further support for this conjecture is provided by the estimates for the upper level CPG expenditure model in Table 12, where we find that only the first three lags of income have a statistically significant impact on spending. The lagged income results are consistent with a permanent income effect, whereby households form future income expectations based on their contemporaneous and past income levels. The evidence is also consistent with a partial adjustment view of private-label demand, whereby households change their purchase habits only slowly. Such persistence in choice behavior has been extensively documented in the brand choice literature (see Dube, Hitsch, and Rossi 2010 for an overview of the literature).

One possible explanation for the statistically significant effect of the first income lag is measurement error. As discussed previously, Nielsen collects the previous year's income in a survey conducted at the end of the fall. If households erroneously report their current-year income, , the first lag of the income variable that is matched to the transaction data using the procedure explained in Section 3.1 would correspond to the true contemporaneous income. The same logic, however, cannot explain the statistically significant higher-order income lags, and hence we conclude, once again, that our results are unlikely to be affected by measurement error.

In summary, we do not find evidence that the income effect estimates are small because of attenuation bias from measurement error. However, we find that private-label demand is affected by current and past income levels, consistent with both a permanent income and a partial adjustment view. Examining the magnitude of the income effects, we find that if we do not control for lagged income the private-label share increases by 0.11 percentage points for a 25 percent income reduction. For a permanent 25 percent income reduction the predicted share increase is 0.38 points, calculated using the effects of both current income and the first four income lags. Hence, the effect from a permanent income change is significantly larger than the effect from a contemporaneous income change. Nonetheless, in absolute terms the income effect is small. Real median household incomes in the U.S. decreased by less than 10 percent in the years during and after the Great Recession 
relative to the peak value in $2007 .^{18}$ The corresponding predicted effect on the overall private-label share is an increase of less than 0.14 points. Even for a large income change, for example if a household becomes unemployed and experiences a permanent 60 percent drop in income, the predicted private-label share of 1.6 points is modest when compared to the overall private-label-share level.

\subsection{Are private-label products inferior goods?}

So far we have established that the private-label expenditure share is decreasing in householdlevel income and housing wealth. However, this finding does not directly imply that private-label products are inferior goods. Both the demand for private-label products and national brands are affected by income and wealth. Suppose that private-label and national-brand demand increases in income and wealth, but that the demand for national brands increases at a faster rate than the demand for private-label products. The private-label share is then decreasing in income and wealth, even though private-label products are normal goods.

The Marshallian demand for private-label products corresponding to the model in Section 6.1 is given by

$$
Q_{P L}=s \frac{y_{C P G}}{P_{P L}} .
$$

Again, to simplify the notation, we he have omitted household and time subscripts. The income elasticity of private-label demand is therefore

$$
\begin{aligned}
e_{P L} & =\frac{\partial \log \left(Q_{P L}\right)}{\partial \log (I)}=\frac{\partial \log (s)}{\partial \log (I)}+\frac{\partial \log \left(y_{C P G}\right)}{\partial \log (I)} \\
& =\frac{\gamma_{I}}{s}+\delta_{I}
\end{aligned}
$$

The income elasticity of private-label demand depends on the income elasticity of the private-label expenditure share and the income elasticity of total CPG expenditure. The household wealth elasticity is derived analogously. Based on our findings above in Section 6.4 we also incorporate lagged $(\log )$ income levels in the upper and lower level demand equations. Generalizing the income elasticity formula (8) to this case is straightforward. Let $\delta_{I,-l}$ and $\gamma_{I,-l}$ be the parameters corresponding to the $l^{\text {th }}$ income lag in upper and lower level demand. The elasticity of private-label demand with respect to a permanent income change is then given by

$$
\bar{e}_{P L}=\frac{1}{s} \sum_{l=0}^{L} \gamma_{I,-l}+\sum_{l=0}^{L} \delta_{I,-l} .
$$

To estimate the income elasticity (8) we fit the upper level CPG expenditure model (3). The

\footnotetext{
${ }^{18}$ US. Bureau of the Census, Real Median Household Income in the United States [MEHOINUSA672N], retrieved from FRED, Federal Reserve Bank of St. Louis https://research.stlouisfed.org/fred2/series/MEHOINUSA672N/, April 25, 2015.
} 
corresponding results are reported in Table $12 .{ }^{19}$ We use the same price level controls that we used in the lower level AIDS share regression, and in column (3) we also include recession and postrecession indicators and the trend variables. In column (4) we add the first four lags of log income to the expenditure equation. The estimates of the first three lags are all statistically significant, while the fourth lag is not statistically different from zero. Also, the effect of the first income lag on CPG spending is larger than the contemporaneous effect. The effect sizes are declining for the lags of order $l>1$. Based on the model including all lags (4), the estimated income elasticity of CPG expenditure with respect to contemporaneous income is 0.025 . This income effect is small but precisely estimated. The elasticity with respect to a permanent income change is substantially larger, 0.124. The estimated wealth effect is smaller and not statistically different from zero.

In Table 13 we report the predicted income and wealth elasticities of demand. The predicted elasticities of the private-label expenditure share are evaluated at the median private-label share across households (see equation 8). We find that the point estimate of the income elasticity of private-label demand is positive both for contemporaneous and permanent income changes, indicating that the private-label product group is a normal good. However, a 95 percent confidence interval includes a range of negative and positive values. Hence, despite the positive point estimates we cannot be sure if the private-label product group is an inferior or normal good. The economic significance of the income elasticity estimates is small. For instance, a 10 percent permanent increase in income would increase private-label demand by about 0.53 percent, while the corresponding contemporaneous income effect on private-label demand is only about 0.04 percent. The estimated wealth elasticity is also small and not statistically different from zero.

\section{Sources of private-label-share growth}

A key finding of our analysis (see, for example, the trend coefficient in Table 8) is the strong positive trend in the private-label share of 0.44 percentage points per year. The trend appears to be the main source of private-label growth over our sample period, whereas the effects of income and wealth shocks were comparatively small. In this section we investigate the role of product quality and new private-label product introductions as possibles sources of this trend.

\section{Private-label product quality}

We investigate whether the upward trend in the private-label share was uniform or concentrated in specific private-label quality tiers. Some articles in the trade press suggest that the private-labelshare growth reflects the increasing availability of high-quality private-label products (PR Newswire 2011). Describing the increasing availability of high-quality private-label products, Kumar and Steenkamp 2007 argue that "it is almost as if quality has now become a commodity." They note that several leading US retail chains have produced private-label alternatives that are now higher-

\footnotetext{
${ }^{19}$ Table 19 provides estimates of the upper level demand equation using price indices with fixed region weights. Table 15 provides the results for only food products.
} 
rated than their national-brand counterparts in Consumer Reports. According to Sarah Theodore, a beverage analyst at Mintel International: "Private label has really been gaining ground for several years now because retailers have put a lot more emphasis on quality. They've really created brands that can stand up to national brands, and that's something that's been going on for quite a while now. The recession has kind of accelerated this trend a little bit, and in some categories more than others. But it was a movement that was taking place long before the economy fell apart" (Rouan 2010).

Either due to demand-side or supply-side factors, the private-label share increase could be due to increased spending on high-quality private-label products that are similar to national brands along their actual or perceived attributes. Unfortunately, we do not have a direct measure of product quality as there is no consistent source measuring private-label quality during our sample period. ${ }^{20}$ Instead, we define an indirect measure of quality based on the relative private-label/national-brand product price. Our analysis will therefore explore whether the trend in overall private-label shares appears to be associated with a trend towards purchasing private labels with prices comparable to those of the national-brand counterparts. Such a definition is meaningful if the relative price of a private-label product is positively correlated with its quality. Although plausible, we cannot test this assumption.

We calculate the relative private-label/national-brand prices using the transaction prices from the Homescan data, not the offered prices from the RMS data. This allows us to classify and analyze all private-label products in our data, not just those sold by the retailers observed in the RMS data. To classify the private-label products into different quality tiers we use the following approach.

(i) We focus on product groups that are in the same category and have volumes that are measured in the same equivalent units, such as ounces or pounds. This allows us to express prices in equivalent units that can be compared across different products.

(ii) We calculate the median monthly price (in equivalent units) of each product based on the observed transaction prices in the Homescan data.

(iii) For the national-brand products, we calculate the monthly product-group median across all product prices calculated in (ii).

(iv) Even at the monthly level there are often few or no price observations for a given product. Hence, for each private-label product and month $t$ we calculate the median of the prices in (ii) over all periods $t-11, \ldots, t$. We also calculate an analogous moving average for the nationalbrand product group prices in (iii). The relative price of a private-label product is then given by the ratio of the private-label and national-brand product group moving averages.

\footnotetext{
${ }^{20}$ Apelbaum, Gerstner, and Naik 2003 use data collected from Consumer Reports. However, for our sample period Consumer Reports did not systematically provide a consistent measure of private-label versus national-brand quality across CPG categories. Conducting a survey of retailers, as in Hoch and Banerji 1993, is beyond the scope of this paper.
} 
We repeatedly use medians, not (weighted) averages in this approach because the observations for any given product are sparse and because we would like to minimize the resulting influence of outliers on our results.

Based on these relative prices, we classify the private-label products into different quality tiers based on the thresholds $0.6,0.7,0.8,0.9$, and 1 . The tier of private-label products with the lowest quality are those with relative price $r_{j t}<0.6$. The second lowest quality tier is defined as $0.6 \leq r_{j t}<0.7$, etc. We correspondingly obtain six quality tiers. By design, this approach allows product $j$ to be in different quality tiers across time if its relative price changes significantly.

In Figure 7, we show the evolution of the private-label share during 2004-2011 in each quality tier. In each tier the average share (across months) increased from 2004 to 2011. The largest increases were in the $>100 \%$ tier (0.82 points) and in the $70-80 \%$ tier (0.70 points), although, as a percentage of the base share, the increase was somewhat larger in the $70-80 \%$ tier than in the $>100 \%$ tier. The smallest increases were in the $90-100 \%$ tier $(0.15$ points $)$ and in the $\leq 60 \%$ group (0.19 points); the latter increase was the smallest as a percentage of the base share. Overall, it does not appear that there was a strong, systematic relationship between the private-label-share growth and the quality level of the products.

\section{New product introductions}

The positive trend in the private-label share may reflect new product introductions by the retailers. In a recent report, IRI describes private-label products as alternatives that "bring something new to the market... new products, new attributes, new sizes... private labels are opening doors to attributes which have historically been out of the reach of many consumers by bringing them into an affordable price range." 21

In Figure 8, we show the number of new products introduced in each month from 2006 to 2011, separately for private-label and national-brand products. We classify a product as "new" if there is no purchase record for the product in the Homescan data in 2004 or 2005. The number of new product introductions per month is substantial, and the number of national-brand product introductions is larger than the number of private-label product introductions. The count of new products may be misleading, however, because we equate products with UPC's, and hence any slight modification of an existing product counts as a new product. Alternatively, in Figure 9, we display the private-label and national-brand new-product-expenditure shares. Here, we classify a product as "new" in a given month if it was either introduced within the last 12 months (left panel) or within the last 24 months (right panel). The new product share of national brands is substantially larger than the new private-label share, although this may simply reflect the overall size difference between the national-brand and private-label share. Hence, in the middle row we show the within-private-label and within-national-brand new product shares. The within-share of

\footnotetext{
${ }^{21}$ The report is available online at:

http://www.symphonyiri.com/Insights/Publications/TimesTrends/tabid/106/Default.aspx.
} 
new private-label products is defined as

$$
\frac{\text { expenditure on new PL products }}{\text { total PL expenditure }}
$$

and hence measures the importance of new product sales relative to the total expenditure volume on private-label products. Controlling for the differences in the overall expenditure levels, we still find that the new product share is larger for national brands than for private-label products, although the difference is not large. Therefore, the upward trend in the overall private-label product share is not related to a relatively higher degree of new product introductions (or adoption) of private-label products compared to national brands. In Figure 10, we show the new private-label product share as a percentage of the total private-label expenditure in each of the six quality tiers. We find that the new product share is somewhat larger in the top quality tier $(>100 \%)$ than in any of the other tiers, suggesting that new product introductions played a relatively larger role in the growth of the highest quality private-label brands.

In summary, the overall trend in the private-label share is not consistently related to the quality level of the products. Furthermore, we do not find evidence that the trend is due to a relatively higher rate of new private-label product introductions compared to new national-brand product introductions. New products account for a somewhat larger fraction of the private-label share of the highest quality products than for the lower quality products, although the quantitative contribution of these new high-quality products to the overall trend is small.

\section{Conclusions}

This paper provides clear evidence for a negative causal effect of income on the private-label share in CPG expenditures, whereas the estimated wealth effect is also negative but not statistically different from zero. The elasticity of demand for the private-label product group with respect to income is small and positive, but a 95 percent confidence interval contains both positive and negative values. Previous work on the relationship between income and private-label shares has either relied on cross-sectional or aggregate time series analyses. Our approach to estimating causal effects of income exploits within-household variation in income controlling for selection or cohort effects which afflict cross-sectional analyses. The Great Recession provides the key source of income and wealth variation in our data. In particular, the effect of the Great Recession on economic conditions was large and there were large differences in the impact of the recession across regions and households, a fact we use to justify that within-household income and wealth changes are as good as randomly assigned conditional on other controls.

The estimates of the causal effect of income are small and smaller than those obtained using the cross-sectional variation in our panel data. Selection could be at the root of the difference between results obtained from the cross-sectional versus within-household variation in the data. That is, there is an unobservable characteristic of households which is correlated with income and 
the demand for private-label versus national-brand products. It is also possible that there are cohort effects which mask the true causal relationship between income and private-label demand. For example, suppose older consumers have a different perception of quality differences between national-brand and private-label products than younger cohorts as well as higher income and wealth. Then in the cross-section, these cohort effects could induce a correlation between income and privatelabel demand. While we feel confident that we can identify the causal impact of income from our household panel data, we do not identify the unobservable factors which may lead to a spuriously high level of correlation between income and private-label demand. Clearly, understanding these unobservables should be one of the goals of the private-label research agenda.

To interpret the estimated income and wealth effects as causal we also need to condition on local market conditions, in particular prices, that may be correlated with within-household changes in income and wealth. Hence we construct local national-brand and private-label price indices that are customized to each household's spending patterns. Conditional on these price controls, we can interpret the income and wealth effects on private-label demand as valid direct demand effects as defined in the microeconomic theory of the consumer.

The estimated income effects are precisely measured but small. A sensitivity analysis shows that the small effect size is unlikely to be the result of attenuation bias due to measurement error. We also extend the analysis beyond a contemporaneous relationship between income and privatelabel shares and also add lagged income levels to our specification. We find significant lagged relationships. This evidence is consistent with a permanent income explanation, but also with a form of partial adjustment whereby purchase patterns change only slowly.

The small economic significance of the income estimates is in stark contrast to some prior work in marketing research, and at odds with many views voiced in the industry at the time of the Great Recession. The differences between our findings and the results in some prior studies (e.g. Lamey, Deleersnyder, Dekimpe, and Steenkamp 2007) can be explained in a variety of ways. First, we have different data sources with a much larger number of products and a different (more recent) time span. Second, our identification strategy relies on differences across households in the withinhousehold variation in income and wealth that, as we argued, is plausibly exogenous or "as good as randomly assigned" conditional on supply-side controls. Such an analysis is feasible even when controlling for a flexible overall trend or time-specific effects. An analysis using aggregate time series data as the basis for causal inference is based on the assumption that the counterfactual private-label demand outcome in the absence of aggregate income changes during a recession can be predicted or extrapolated using a trend based on pre-recession data. This is a different identification strategy and one can debate which set of assumptions is more or less plausible for the purpose of causal inference.

We also document the supply response of national brand and private labels to the Great Recession. Contrary to the views expressed in the industry press, we do not find that national-brand manufacturers reduced the effective price of national-brand products relative to private-label products. 
Our estimates reveal a large trend in the private-label share that predates the years of the Great Recession. The trend does not stem systematically from specific private-label quality tiers, although we can only imperfectly proxy for product quality using relative private-label versus national-brand price ratios. The trend also appears to be unrelated to the overall rate of private-label versus national-brand product introductions. According to our analysis, the overall trend represents a greater threat to national-brand products than economic downturns. Therefore, an important task for future private-label research is to uncover the origins of the trend before any meaningful conclusions can be made as to what firm policies might alter this trend. 


\section{References}

Ailawadi, K. L., S. A. Neslin, and K. Gedenk (2001): "Pursing the Value-Conscious Consumer: Store Brands versus National Brand Promotions," Journal of Marketing, 65(1), 71-89.

Ailawadi, K. L., K. Pauwels, and J. B. Steenkamp (2008): "Private-Label Use and Store Loyalty," Journal of Marketing, 72, 19-30.

Ang, S.-H., S. M. Leong, and P. Kotler (2000): "The Asian Apocalypse: Crisis Marketing for Consumers and Businesses," Long Range Planning, 33, 97-119.

Apelbaum, E., E. Gerstner, and P. Naik (2003): "The Effects of Expert Quality Evaluations Vs. Brand," Journal of Product and Brand Management, 12(3), 154-165.

Batra, R., And I. Sinha (2000): "Consumer-Level Factors Moderating the Success of Private Label Brands," Journal of Retailing, 76(2), 175-191.

Bronnenberg, B. J., J. Dube, M. Gentzkow, and J. M. Shapiro (2014): "Do Pharmacists Buy Bayer? Informed Shoppers and the Brand Premium," Discussion Paper 20295, National Bureau of Economic Research.

Deaton, A., And J. Muellbauer (1980a): "An Almost Ideal Demand System," American Economic Review, 70(3), 312-326.

- (1980b): Economics and Consumer Behavior. Cambridge University Press.

Dhar, S. K., And S. J. Hoch (1997): "Why Store Brand Penetration Varies by Retailer," Marketing Science, 16(3), 2208-227.

Dube, J., G. Hitsch, And P. E. Rossi (2010): "State Dependence and Alternative Explanations for Consumer Inertia," RAND Journal of Economics, 41(3), 417-445.

Erdem, T., Y. Zhao, and A. Valenzuela (2004): "Performance of Store Brands: a crosscountry analysis of consumer store-brand preferences, perceptions and risk," Journal of Marketing Research, XLI, 86-100.

Estelami, H., D. R. Lehmann, and A. C. Holden (2001): "Macro-Economic Determinants of Consumer Price Knowledge: A Meta-Analysis of Four Decades of Research," International Journal of Research in Marketing, 18, 341-355.

Frank, J. N. (2010): "Consumers Plan to Stick with Private Label; Price Remains the Reason," Private Label Buyer, 25, 6.

Gordon, B. R., A. Goldfarb, and Y. Li (2013): "Does Price Elasticity Vary with Economic Growth? A Cross-Category Analysis," Journal of Marketing Research, 50(1), 4-23. 
Guerrieri, V., D. Hartley, and E. Hurst (2010): "Endogenous Gentrificatioin and Housing Price Dynamics," Discussion Paper 16237, National Bureau of Economic Research.

Hammerbeck, P. (2008): "Store Brands: Ignore Them at Your Peril," Brand Packaging.

Hansen, K., V. Singh, and P. Chintagunta (2006): "Understanding Store-Brand Purchase Behavior Across Categories," Marketing Science, 25(1), 75-90.

Hausman, J., G. Leonard, and J. D. Zona (1994): "Competitive Analysis with Differentiated Products," Annales d'Économie et de Statistique, 34, 159-180.

Heerde, H. J. V., M. J. Gijsenberg, M. G. Dekimpe, and J.-B. E. Steenkamp (2013): "Price and Advertising Effectiveness over the Business Cycle," Journal of Marketing Research, 50, 177-193.

Hoch, S. J., And S. BanerJi (1993): "When Do Private Labels Succeed?," Sloan Management Review, 34(4), 57-67.

IACOviello, M. (2011): "Housing Wealth and Consumption," International Finance Discussion Papers 1027, Board of Governors of the Federal Reserve System.

Imbens, G. W., and D. R. Rubin (2015): Causal Inference for Statistics, Social, and Biomedical Sciences: An Introduction. Cambridge University Press.

Kamakura, W. A., And R. Y. Du (2012): "How Economic Contractions and Expansions Affect Expenditure Patterns," JOURNAL OF CONSUMER RESEARCH, 39, 229-247.

Kilts Center for Marketing (2013): "Consumer Panel Dataset Manual," Discussion paper, Booth School of Business, University of Chicago.

Kim, J., G. M. Allenby, and P. E. Rossi (2002): "Modeling Consumer Demand for Variety," Marketing Science, 21(3), 229-250.

Kumar, N., And J.-B. E. M. Steenkamp (2007): Private Label Strategy: How to Meet the Store Brand Challenge. Harvard Business Review Press.

Lamey, L., B. Deleersnyder, M. G. Dekimpe, and J. B. Steenkamp (2012): "The Effect of Business-Cycle Fluctuations on Private-Label Share: What Has Marketing Conduct Got to Do With It?," Journal of Marketing, 76, 1-19.

Lamey, L., B. Deleersnyder, M. G. Dekimpe, and J.-B. E. Steenkamp (2007): "How Business Cycles Contribute to Private-Label Success: Evidence from the United States and Europe," Journal of Marketing, 71(1), 1-15.

Mian, A., A. Sufi, And F. Trebbi (2011): "Foreclosures, House Prices, and the Real Economy," Discussion Paper 16685, National Bureau of Economic Research. 
Murphy, P. E., and G. R. Laczniak (1979): "Generic Supermarket Items: A Product and Consumer Analysis," Journal of Retailing, 55(2), 3-14.

Nevo, A., And A. Wong (2014): "The Elasticity of Substitution Between Time and Market Goods: Evidence from the Great Recession," Discussion paper, Northwestern University.

Nielsen (2011): "Private Brand U.S. Outlook," Discussion paper, The Nielsen Company.

PR Newswire (2011): "Private Label Gets a Quality Reputation, Causing Consumers to Change Their Buying Habits," PR Newswire, January 20.

Quelch, J. A., And D. Harding (1996): "Brands Versus Private Labels: fighting to win," Harvard Business Review, 1, 99-109.

Raju, J. S., R. Seethuraman, and S. K. Dhar (1995): "The Introduction and Performance of Store Brands," Management Science, 41, 957-978.

Rosen, D. L. (1984): "Consumer Perceptions of Quality for Generic Grocery Products: A Comparison across product Categories," Journal of Retailing, 60, 64-80.

Rouan, R. (2010): "A new label on quality," Beverage Industry, 101.9, 22-23.

Stroebel, J., and J. Vavra (2014): "House Prices, Local Demand, and Retail Prices," NBER Working Paper 20710.

ter Braak, A., I. Geyskens, and M. G. Dekimpe (2014): "Taking Private Labels Upmarket: Empirical Generalizations on Category Drivers of Premium Private Label Introductions," Journal of Retailing, 90(2), 125-140.

Wong, E. (2008): "Will Private Label Clean Up Now?," Brandweek, 49, S40-42. 
Table 1: Homescan Sample Size

\begin{tabular}{|c|c|c|c|c|c|}
\hline Year & & Households & $\begin{array}{l}\text { Trips } \\
(\mathrm{mm})\end{array}$ & $\begin{array}{r}\text { Transactions } \\
(\mathrm{mm})\end{array}$ & $\begin{array}{r}\text { Expenditures } \\
(\$ \mathrm{~mm})\end{array}$ \\
\hline \multirow[t]{3}{*}{2004} & Raw & 39,577 & 5.7 & 38.7 & 129.2 \\
\hline & Filtered & 31,878 & 4.6 & 30.7 & 100.8 \\
\hline & Income-Matched & 27,977 & 3.5 & 22.9 & 75.3 \\
\hline \multirow{3}{*}{2005} & Raw & $\begin{array}{l}38,862 \\
\end{array}$ & 5.5 & 38.4 & 131.3 \\
\hline & Filtered & 32,918 & 4.8 & 32.2 & 108.9 \\
\hline & Income-Matched & 29,496 & 3.7 & 24.6 & 83.0 \\
\hline \multirow[t]{3}{*}{2006} & Raw & 37,783 & 5.2 & 36.0 & 127.4 \\
\hline & Filtered & 31,866 & 4.5 & 30.7 & 107.9 \\
\hline & Income-Matched & 28,419 & 3.6 & 23.8 & 83.1 \\
\hline \multirow[t]{3}{*}{2007} & Raw & 63,345 & 8.2 & 60.2 & 222.9 \\
\hline & Filtered & 53,319 & 7.2 & 51.7 & 190.8 \\
\hline & Income-Matched & 42,892 & 5.3 & 36.5 & 134.4 \\
\hline \multirow[t]{3}{*}{2008} & Raw & 61,437 & 7.9 & 57.6 & 223.7 \\
\hline & Filtered & 52,204 & 7.0 & 49.8 & 193.3 \\
\hline & Income-Matched & 41,300 & 5.1 & 35.4 & 137.2 \\
\hline \multirow[t]{3}{*}{2009} & Raw & 60,502 & 7.7 & 56.3 & 222.7 \\
\hline & Filtered & 52,134 & 6.9 & 49.3 & 195.0 \\
\hline & Income-Matched & 40,469 & 5.1 & 34.8 & 137.6 \\
\hline \multirow[t]{3}{*}{2010} & Raw & 60,654 & 7.7 & 55.1 & 222.3 \\
\hline & Filtered & 53,371 & 7.0 & 48.5 & 192.2 \\
\hline & Income-Matched & 42,511 & 5.1 & 34.9 & 138.4 \\
\hline \multirow[t]{2}{*}{2011} & Raw & 62,085 & 8.0 & 56.9 & 236.1 \\
\hline & $\begin{array}{l}\text { Filtered } \\
\text { Income-Matched }\end{array}$ & 55,526 & 7.4 & 50.5 & 206.9 \\
\hline \multirow[t]{2}{*}{2012} & Raw & 60,534 & 7.5 & 53.8 & 230.2 \\
\hline & $\begin{array}{l}\text { Filtered } \\
\text { Income-Matched }\end{array}$ & 52,786 & 6.8 & 46.6 & 195.1 \\
\hline
\end{tabular}

Note: The filtering procedure is described in Section 3.1. The rows indicated as "Income-Matched" summarize all observations in household years $t$ that can be matched to the income that is reported in the year $t+2$ data (see Section 3.1). Correspondingly, there are no such matched observations in the last two sample years, 2011 and 2012. 
Table 2: Comparison of the Distribution of Demographics: Census CPS vs. Homescan

\begin{tabular}{llrr}
\hline & & Census-CPS & Homescan \\
\hline Age & & 6 & \\
& $<5$ & 18 & 2 \\
& $5-17$ & 10 & 6 \\
$18-24$ & 27 & 17 \\
& $25-44$ & 26 & 41 \\
& $45-64$ & 13 & 19 \\
& $65+$ & & \\
Education & & & 4 \\
& $<$ HS & 28 & 25 \\
& HS & 18 & 30 \\
& Some College & 9 & 12 \\
& College & & \\
& Graduate & $\$ 11,904$ & $\$ 17,500$ \\
& & $\$ 20,000$ & $\$ 27,500$ \\
& 10th Pctl & $\$ 49,445$ & $\$ 55,000$ \\
& 20th Pctl & $\$ 100,065$ & $\$ 85,000$ \\
& 50th Pctl & $\$ 138,923$ & $\$ 112,500$ \\
\hline & 80th Pctl & &
\end{tabular}

Table 3: Private-Label Shares Across Household-Years

\begin{tabular}{lll}
\hline Statistic & PL Share & $\begin{array}{l}\text { PL Share: } \\
\text { Food Only }\end{array}$ \\
\hline Mean & 19.50 & 20.66 \\
St. Dev. & 10.76 & 11.86 \\
5th Pctl. & 9.09 & 9.15 \\
25th Pctl. & 13.79 & 14.39 \\
Median & 19.18 & 20.37 \\
75th Pctl. & 26.41 & 28.33 \\
95th Pctl. & 73.12 & 74.08 \\
\hline N. Obs. & 416,001 & 415,968 \\
\hline
\end{tabular}

Note: The data are pooled over all household-years. The reported statistics are weighted using the projection factors. We normalize the projection factors to sum to one within each year. 
Table 4: Pre-Trend Analysis

\begin{tabular}{|c|c|c|c|c|c|}
\hline Pre-recession & Recession & Estimate & $t$-value & $\operatorname{Pr}\{>|t|\}$ & No. obs. \\
\hline \multicolumn{6}{|l|}{ All Products } \\
\hline \multicolumn{6}{|c|}{ Private-Label Share/Unemployment } \\
\hline $2004 / 2006$ & $2007 / 2009$ & -0.042 & -1.974 & 0.049 & 2,185 \\
\hline $2005 / 2006$ & $2007 / 2009$ & -0.007 & -0.331 & 0.741 & 2,183 \\
\hline Q1 2004/Q1 2007 & Q2 2007/Q2 2009 & -0.027 & -1.267 & 0.205 & 2,147 \\
\hline Q1 2005/Q1 2007 & Q2 2007/Q2 2009 & 0.018 & 0.861 & 0.389 & 2,195 \\
\hline Q1 2006/Q1 2007 & Q2 2007/Q2 2009 & -0.012 & -0.562 & 0.574 & 2,199 \\
\hline \multicolumn{6}{|c|}{ Private-Label Share/Log Zillow Index } \\
\hline $2004 / 2006$ & $2007 / 2009$ & 0.001 & 0.109 & 0.913 & 5,985 \\
\hline $2005 / 2006$ & $2007 / 2009$ & -0.028 & -2.135 & 0.033 & 5,934 \\
\hline Q1 2004/Q1 2007 & Q2 2007/Q2 2009 & -0.001 & -0.068 & 0.946 & 5,793 \\
\hline Q1 2005/Q1 2007 & Q2 2007/Q2 2009 & -0.027 & -2.051 & 0.040 & 5,985 \\
\hline Q1 2006/Q1 2007 & Q2 2007/Q2 2009 & -0.022 & -1.720 & 0.086 & 6,067 \\
\hline \multicolumn{6}{|c|}{ Private-Label Share/Log Income } \\
\hline $2004 / 2006$ & $2007 / 2009$ & 0.007 & 0.795 & 0.427 & 13,931 \\
\hline $2005 / 2006$ & $2007 / 2009$ & 0.003 & 0.327 & 0.744 & 15,797 \\
\hline Q1 2004/Q1 2007 & Q2 2007/Q2 2009 & 0.000 & -0.058 & 0.954 & 13,931 \\
\hline Q1 2005/Q1 2007 & Q2 2007/Q2 2009 & 0.000 & -0.035 & 0.972 & 15,794 \\
\hline Q1 2006/Q1 2007 & Q2 2007/Q2 2009 & -0.003 & -0.336 & 0.737 & 17,179 \\
\hline \multicolumn{6}{|l|}{ Food } \\
\hline \multicolumn{6}{|c|}{ Private-Label Share/Unemployment } \\
\hline $2004 / 2006$ & $2007 / 2009$ & -0.037 & -1.711 & 0.087 & 2,180 \\
\hline $2005 / 2006$ & $2007 / 2009$ & -0.002 & -0.092 & 0.927 & 2,182 \\
\hline Q1 2004/Q1 2007 & Q2 2007/Q2 2009 & -0.009 & -0.438 & 0.662 & 2,145 \\
\hline Q1 2005/Q1 2007 & Q2 2007/Q2 2009 & 0.030 & 1.406 & 0.160 & 2,194 \\
\hline Q1 2006/Q1 2007 & Q2 2007/Q2 2009 & -0.006 & -0.290 & 0.772 & 2,198 \\
\hline \multicolumn{6}{|c|}{ Private-Label Share/Log Zillow Index } \\
\hline $2004 / 2006$ & $2007 / 2009$ & -0.006 & -0.472 & 0.637 & 5,970 \\
\hline $2005 / 2006$ & $2007 / 2009$ & -0.026 & -1.995 & 0.046 & 5,932 \\
\hline Q1 2004/Q1 2007 & Q2 2007/Q2 2009 & -0.003 & -0.233 & 0.815 & 5,791 \\
\hline Q1 2005/Q1 2007 & Q2 2007/Q2 2009 & -0.019 & -1.502 & 0.133 & 5,984 \\
\hline Q1 2006/Q1 2007 & Q2 2007/Q2 2009 & -0.020 & -1.573 & 0.116 & 6,066 \\
\hline \multicolumn{6}{|c|}{ Private-Label Share/Log Income } \\
\hline $2004 / 2006$ & $2007 / 2009$ & 0.001 & 0.154 & 0.877 & 13,931 \\
\hline $2005 / 2006$ & $2007 / 2009$ & 0.009 & 1.095 & 0.273 & 15,797 \\
\hline Q1 2004/Q1 2007 & Q2 2007/Q2 2009 & -0.011 & -1.243 & 0.214 & 13,931 \\
\hline Q1 2005/Q1 2007 & Q2 2007/Q2 2009 & 0.003 & 0.333 & 0.739 & 15,794 \\
\hline Q1 2006/Q1 2007 & Q2 2007/Q2 2009 & -0.004 & -0.584 & 0.559 & 17,179 \\
\hline
\end{tabular}

Note: This table reports the estimated correlation coefficients between the change in the private-label share in the pre-recession period and the change in unemployment, the log Zillow index, and log income during the recession period. The results are reported for different time period definitions over which the changes are calculated. For example, "2004/2006" indicates the difference between the average of the variable in 2004 and 2006. "Q2 2007/Q2 2009" indicates the difference between the average of the variable in the second quarter of 2007 and the second quarter of 2009. 
Table 5: Private-Label-Share Regression

\begin{tabular}{|c|c|c|c|c|c|}
\hline & pooled & $\begin{array}{l}\text { between } \\
+ \text { demog }\end{array}$ & Within & $\begin{array}{l}\text { withing } \\
+ \\
\text { recession }\end{array}$ & $\begin{array}{l}\text { within }+ \\
\text { recession } \\
+ \text { trend }\end{array}$ \\
\hline $\log ($ Income $)$ & $\begin{array}{c}-2.55 \\
(0.0967)\end{array}$ & $\begin{array}{l}-2.93 \\
(0.18)\end{array}$ & $\begin{array}{l}-0.479 \\
(0.0669)\end{array}$ & $\begin{array}{l}-0.345 \\
(0.0654)\end{array}$ & $\begin{array}{l}-0.412 \\
(0.0654)\end{array}$ \\
\hline $\log ($ Wealth$)$ & $\begin{array}{l}-1.35 \\
(0.146)\end{array}$ & $\begin{array}{l}-1.23 \\
(0.173)\end{array}$ & $\begin{array}{l}-2.38 \\
(0.119)\end{array}$ & $\begin{array}{l}-0.01 \\
(0.129)\end{array}$ & $\begin{array}{l}-0.545 \\
(0.141)\end{array}$ \\
\hline $\mathbb{I}\{$ Unemployed $\}$ & $\begin{array}{c}0.00438 \\
(0.13)\end{array}$ & $\begin{array}{l}-0.314 \\
(0.213)\end{array}$ & $\begin{array}{l}0.268 \\
(0.0837)\end{array}$ & $\begin{array}{l}0.358 \\
(0.0814)\end{array}$ & $\begin{array}{l}0.373 \\
(0.0812)\end{array}$ \\
\hline High School & $\begin{array}{c}0.342 \\
(0.273)\end{array}$ & $\begin{array}{l}0.695 \\
(0.29)\end{array}$ & & & \\
\hline Some College & $\begin{array}{c}0.228 \\
(0.144)\end{array}$ & $\begin{array}{l}0.394 \\
(0.154)\end{array}$ & & & \\
\hline College & $\begin{array}{c}0.718 \\
(0.134)\end{array}$ & $\begin{array}{l}0.612 \\
(0.149)\end{array}$ & & & \\
\hline Post Graduate & $\begin{array}{c}0.503 \\
(0.169)\end{array}$ & $\begin{array}{l}0.711 \\
(0.156)\end{array}$ & & & \\
\hline $\log ($ Age $)$ & $\begin{array}{c}3.32 \\
(0.264)\end{array}$ & $\begin{array}{l}2.79 \\
(0.271)\end{array}$ & & & \\
\hline No. Adults & $\begin{array}{c}0.16 \\
(0.0712)\end{array}$ & $\begin{array}{l}0.368 \\
(0.101)\end{array}$ & & & \\
\hline No. Children & $\begin{array}{c}1.12 \\
(0.0694)\end{array}$ & $\begin{array}{l}1.21 \\
(0.103)\end{array}$ & & & \\
\hline Female Hh. Head & $\begin{array}{c}-2.86 \\
(0.172)\end{array}$ & $\begin{array}{l}-2.97 \\
(0.169)\end{array}$ & & & \\
\hline Black & $\begin{array}{c}-1.11 \\
(0.197)\end{array}$ & $\begin{array}{l}-1.17 \\
(0.21)\end{array}$ & & & \\
\hline Asian & $\begin{array}{c}-1.69 \\
(0.279)\end{array}$ & $\begin{array}{l}-1.58 \\
(0.271)\end{array}$ & & & \\
\hline Hispanic & $\begin{array}{c}-0.0924 \\
(0.233)\end{array}$ & $\begin{array}{l}-0.0665 \\
(0.23)\end{array}$ & & & \\
\hline Divorced/Separated & $\begin{array}{c}0.686 \\
(0.178)\end{array}$ & $\begin{array}{l}0.608 \\
(0.153)\end{array}$ & & & \\
\hline Widowed & $\begin{array}{c}0.902 \\
(0.241)\end{array}$ & $\begin{array}{l}0.806 \\
(0.222)\end{array}$ & & & \\
\hline Single Hh. Head & $\begin{array}{l}0.293 \\
(0.14)\end{array}$ & $\begin{array}{l}0.233 \\
(0.139)\end{array}$ & & & \\
\hline Mobile Home/Trailer & $\begin{array}{c}1.01 \\
(0.301)\end{array}$ & $\begin{array}{l}1.34 \\
(0.298)\end{array}$ & & & \\
\hline Trend & & & & & $\begin{array}{l}0.0372 \\
(0.00159)\end{array}$ \\
\hline $\mathbb{I}\{$ Recession $\}$ & & & & $\begin{array}{l}1.59 \\
(0.0396)\end{array}$ & $\begin{array}{l}0.322 \\
(0.0427)\end{array}$ \\
\hline
\end{tabular}


Table 5: Private-Label-Share Regression

\begin{tabular}{llllll}
\hline & pooled & $\begin{array}{l}\text { between } \\
+ \text { demog }\end{array}$ & Within & $\begin{array}{l}\text { withing } \\
+\end{array}$ & $\begin{array}{l}\text { within }+ \\
\text { recession } \\
+ \text { trend }\end{array}$ \\
\hline $\mathbb{I}$ \{Post Recession\} & & & & 1.99 & 0.479 \\
& & & & $(0.0527)$ & $(0.0769)$ \\
Trend $\times \mathbb{I}$ \{Recession\} & & & & 0.019 \\
& & & & & $(0.00419)$ \\
Trend $\times \mathbb{I}$ \{Post Rec. & & & & & -0.029 \\
& & & & & $(0.0039)$ \\
\hline Fixed Effects & No & No & Hh. & Hh. & Hh. \\
No. Obs. & $1,716,936$ & 39,856 & $1,716,947$ & $1,716,947$ & $1,716,947$ \\
No. Missing & $3,185,586$ & 0 & $3,185,575$ & $3,185,575$ & $3,185,575$ \\
No. Clusters & 39,413 & 195 & 39,413 & 39,413 & 39,413 \\
$R^{2}$ & 0.0723 & 0.122 & 0.567 & 0.569 & 0.57 \\
\hline
\end{tabular}


Table 6: National-Brand/Private-Label Price Indices by Year

\begin{tabular}{cc}
\hline Year & $\begin{array}{c}\text { Mean NB/PL Price } \\
\text { Ratio }\end{array}$ \\
\hline & \\
2006 & 1.0000 \\
2007 & 1.0013 \\
2008 & 1.0062 \\
2009 & 1.0201 \\
2010 & 1.0200 \\
2011 & 1.0186 \\
\hline
\end{tabular}

Table 7: National-Brand/Private-Label Price Ratios and Local Economic Factors

\begin{tabular}{|c|c|c|c|c|}
\hline & $\Delta \log \left(P_{N B}\right)$ & Regional & $\Delta \log \left(P_{N B} / 1\right.$ & Iousehold \\
\hline & (1) & $(2)$ & $(3)$ & (4) \\
\hline Constant & $0.0028 * *$ & $0.0126 * *$ & $0.0026 * *$ & $0.0131 * *$ \\
\hline & $(0.0001)$ & $(0.0001)$ & $(0.0001)$ & $(0.0002)$ \\
\hline 2008 & $0.0022 * *$ & $0.0085 * *$ & $0.0021 * *$ & $0.0089 * *$ \\
\hline & $(0.0001)$ & $(0.0001)$ & $(0.0002)$ & $(0.0002)$ \\
\hline 2009 & $0.0083 * *$ & $0.0036 * *$ & $0.0072 * *$ & $0.0022 * *$ \\
\hline & $(0.0001)$ & $(0.0001)$ & $(0.0003)$ & $(0.0003)$ \\
\hline 2010 & $-0.0042 * *$ & $-0.0162 * *$ & $-0.0050 * *$ & $-0.0178 * *$ \\
\hline & $(0.0001)$ & $(0.0002)$ & $(0.0001)$ & $(0.0003)$ \\
\hline$\Delta \log ($ Zillow $)$ & $-0.0024 * *$ & $-0.0013 * *$ & $-0.0032 * *$ & $-0.0020 * *$ \\
\hline & $(0.0003)$ & $(0.0003)$ & $(0.0005)$ & $(0.0005)$ \\
\hline$\Delta$ Unemployment & $0.0009 * *$ & $0.0006 * *$ & $0.0011 * *$ & $0.0008 * *$ \\
\hline & $(0.00004)$ & $(0.00003)$ & $(0.0001)$ & $(0.0001)$ \\
\hline$\Delta \log$ (HH Real Income) & $-0.0002 *$ & $-0.0002 *$ & -0.0002 & -0.0002 \\
\hline & $(0.0001)$ & $(0.0001)$ & $(0.0002)$ & $(0.0002)$ \\
\hline$\Delta \log (P)$ Regional & & $-0.3273 * *$ & & $-0.3503 * *$ \\
\hline & & $(0.0036)$ & & $(0.0071)$ \\
\hline No. obs. & 130,539 & 130,539 & 130,539 & 130,539 \\
\hline $\mathrm{R}^{2}$ & 0.3919 & 0.4267 & 0.1468 & 0.1611 \\
\hline
\end{tabular}

Note: ${ }^{*} p<0.05,{ }^{* *} p<0.01$ 
Table 8: Lower Level Demand: AIDS Private-Label-Share System

\begin{tabular}{|c|c|c|c|}
\hline & $\begin{array}{c}\text { within }+ \\
\text { recession } \\
+ \text { trend }\end{array}$ & $\begin{array}{l}\text { CPG } \\
\text { prices }\end{array}$ & $\begin{array}{c}\text { CPG } \\
\text { prices }+ \\
\text { proxies } \\
\end{array}$ \\
\hline $\log ($ Income $)$ & $\begin{array}{c}-0.412 \\
(0.0654)\end{array}$ & $\begin{array}{c}-0.377 \\
(0.0718)\end{array}$ & $\begin{array}{c}-0.38 \\
(0.0713)\end{array}$ \\
\hline $\log ($ Wealth$)$ & $\begin{array}{l}-0.545 \\
(0.141)\end{array}$ & $\begin{array}{c}-0.149 \\
(0.164)\end{array}$ & $\begin{array}{c}-0.16 \\
(0.164)\end{array}$ \\
\hline $\mathbb{I}\{$ Unemployed $\}$ & $\begin{array}{c}0.373 \\
(0.0812)\end{array}$ & $\begin{array}{c}0.34 \\
(0.0905)\end{array}$ & $\begin{array}{c}0.353 \\
(0.0906)\end{array}$ \\
\hline Trend & $\begin{array}{c}0.0372 \\
(0.00159)\end{array}$ & $\begin{array}{c}0.0351 \\
(0.00402)\end{array}$ & $\begin{array}{c}0.0368 \\
(0.00456)\end{array}$ \\
\hline $\mathbb{I}\{$ Recession $\}$ & $\begin{array}{c}0.322 \\
(0.0427)\end{array}$ & $\begin{array}{c}0.175 \\
(0.0453)\end{array}$ & $\begin{array}{c}0.138 \\
(0.0489)\end{array}$ \\
\hline $\mathbb{I}\{$ Post Recession $\}$ & $\begin{array}{c}0.479 \\
(0.0769)\end{array}$ & $\begin{array}{c}0.296 \\
(0.108)\end{array}$ & $\begin{array}{c}0.24 \\
(0.111)\end{array}$ \\
\hline Trend $\times \mathbb{I}\{$ Recession $\}$ & $\begin{array}{c}0.019 \\
(0.00419)\end{array}$ & $\begin{array}{c}0.0107 \\
(0.00589)\end{array}$ & $\begin{array}{c}0.011 \\
(0.00655)\end{array}$ \\
\hline Trend $\times \mathbb{I}\{$ Post Rec. $\}$ & $\begin{array}{c}-0.029 \\
(0.0039)\end{array}$ & $\begin{array}{l}-0.0229 \\
(0.0054)\end{array}$ & $\begin{array}{c}-0.0295 \\
(0.00578)\end{array}$ \\
\hline $\log ($ PI National Brand $)$ & & $\begin{array}{c}1.38 \\
(5.84)\end{array}$ & $\begin{array}{c}2.69 \\
(5.65)\end{array}$ \\
\hline $\log ($ PI Private Label $)$ & & $\begin{array}{c}2.92 \\
(1.36)\end{array}$ & $\begin{array}{c}2.64 \\
(1.35)\end{array}$ \\
\hline $\log ($ PI All CPG $)$ & & $\begin{array}{c}1.82 \\
(6.15)\end{array}$ & $\begin{array}{l}0.843 \\
(5.94)\end{array}$ \\
\hline $\log (\mathrm{CPI})$ & & & $\begin{array}{l}0.511 \\
(1.01)\end{array}$ \\
\hline $\log$ (PI Gen. Merchandise) & & & $\begin{array}{c}-2.21 \\
(0.667)\end{array}$ \\
\hline Fixed Effects & Hh. & Hh. & Hh. \\
\hline No. Obs. & $1,716,947$ & $1,335,207$ & $1,317,596$ \\
\hline No. Missing & $3,185,575$ & $3,567,315$ & $3,584,926$ \\
\hline No. Clusters & 39,413 & 36,022 & 35,973 \\
\hline$R^{2}$ & 0.57 & 0.576 & 0.578 \\
\hline
\end{tabular}


Table 9: Sensitivity Analysis: AIDS Private-Label-Share System

\begin{tabular}{|c|c|c|c|c|c|c|}
\hline & (1) & $(2)$ & $(3)$ & (4) & $(5)$ & (6) \\
\hline \multirow[t]{2}{*}{$\log ($ Income $)$} & -0.38 & -0.329 & -0.293 & -0.38 & -0.28 & -0.374 \\
\hline & $(0.0713)$ & $(0.0776)$ & $(0.0807)$ & $(0.0713)$ & $(1.3)$ & $(0.0734)$ \\
\hline \multirow[t]{2}{*}{$\log ($ Wealth $)$} & -0.16 & -0.216 & -0.08 & -0.16 & -0.155 & -0.159 \\
\hline & $(0.164)$ & $(0.201)$ & $(0.216)$ & $(0.164)$ & $(0.164)$ & $(0.164)$ \\
\hline \multirow[t]{2}{*}{$\mathbb{I}\{$ Unemployed $\}$} & 0.353 & 0.424 & 0.446 & 0.332 & 0.342 & 0.681 \\
\hline & $(0.0906)$ & $(0.107)$ & $(0.123)$ & $(0.112)$ & $(0.0906)$ & $(1.29)$ \\
\hline \multirow[t]{2}{*}{$\mathbb{I}\{$ Became Unemployed $\}$} & & & & 0.0353 & & \\
\hline & & & & $(0.0939)$ & & \\
\hline \multirow[t]{2}{*}{$\log ($ Income $) \times \mathbb{I}\{$ Unemployed $\}$} & & & & & & -0.0308 \\
\hline & & & & & & $(0.119)$ \\
\hline \multirow[t]{2}{*}{$\log ($ Age $)$} & & & & & -0.921 & \\
\hline & & & & & $(3.43)$ & \\
\hline \multirow[t]{2}{*}{$\log ($ Income $) \times \log ($ Age $)$} & & & & & -0.0244 & \\
\hline & & & & & $(0.318)$ & \\
\hline \multirow[t]{2}{*}{ Trend } & 0.0368 & 0.034 & 0.0405 & 0.0367 & 0.0382 & 0.0368 \\
\hline & $(0.00456)$ & $(0.00532)$ & $(0.00624)$ & $(0.00455)$ & $(0.0046)$ & $(0.00456)$ \\
\hline \multirow[t]{2}{*}{$\mathbb{I}\{$ Recession $\}$} & 0.138 & 0.123 & 0.0988 & 0.139 & 0.151 & 0.138 \\
\hline & $(0.0489)$ & $(0.0579)$ & $(0.0685)$ & $(0.0491)$ & $(0.0493)$ & $(0.0489)$ \\
\hline \multirow[t]{2}{*}{$\mathbb{I}\{$ Post Recession $\}$} & 0.24 & 0.396 & 0.206 & 0.243 & 0.255 & 0.241 \\
\hline & $(0.111)$ & $(0.161)$ & $(0.15)$ & $(0.111)$ & $(0.111)$ & $(0.111)$ \\
\hline \multirow[t]{2}{*}{ Trend $\times \mathbb{I}\{$ Recession $\}$} & 0.011 & 0.0216 & 0.0125 & 0.0111 & 0.0112 & 0.011 \\
\hline & $(0.00655)$ & $(0.00906)$ & $(0.00904)$ & $(0.00655)$ & $(0.00655)$ & $(0.00655)$ \\
\hline \multirow[t]{2}{*}{ Trend $\times \mathbb{I}\{$ Post Rec. $\}$} & -0.0295 & -0.0308 & -0.041 & -0.0293 & -0.0293 & -0.0295 \\
\hline & $(0.00578)$ & $(0.00689)$ & $(0.00798)$ & $(0.00578)$ & $(0.00578)$ & $(0.00578)$ \\
\hline \multirow[t]{2}{*}{$\log ($ PI National Brand $)$} & 2.69 & 1.16 & 1.04 & 2.7 & 2.72 & 2.69 \\
\hline & $(5.65)$ & $(6.78)$ & $(7.81)$ & $(5.65)$ & $(5.65)$ & $(5.65)$ \\
\hline \multirow[t]{2}{*}{$\log ($ PI Private Label $)$} & 2.64 & 2.67 & 3.05 & 2.65 & 2.61 & 2.64 \\
\hline & $(1.35)$ & $(1.61)$ & $(1.96)$ & $(1.35)$ & $(1.35)$ & $(1.35)$ \\
\hline \multirow[t]{2}{*}{$\log (\mathrm{PI}$ All CPG) } & 0.843 & 1.71 & 0.577 & 0.844 & 0.817 & 0.851 \\
\hline & $(5.94)$ & $(7.13)$ & $(8.29)$ & $(5.94)$ & $(5.94)$ & $(5.94)$ \\
\hline \multirow[t]{2}{*}{$\log (\mathrm{CPI})$} & 0.511 & 0.955 & 0.474 & 0.508 & 0.42 & 0.51 \\
\hline & $(1.01)$ & $(1.24)$ & $(1.45)$ & $(1.01)$ & $(1.01)$ & $(1.01)$ \\
\hline \multirow[t]{2}{*}{$\log ($ PI Gen. Merchandise) } & -2.21 & -1.41 & -2.32 & -2.2 & -2.19 & -2.21 \\
\hline & $(0.667)$ & $(0.786)$ & $(0.922)$ & $(0.667)$ & $(0.667)$ & $(0.667)$ \\
\hline Fixed Effects & Hh. & Hh. & Hh. & Hh. & Hh. & Hh. \\
\hline No. Obs. & $1,317,596$ & 918,266 & 663,723 & $1,317,596$ & $1,317,596$ & $1,317,596$ \\
\hline No. Missing & $3,584,926$ & $1,736,382$ & $1,222,781$ & $3,584,926$ & $3,584,926$ & $3,584,926$ \\
\hline No. Clusters & 35,973 & 21,177 & 14,998 & 35,973 & 35,973 & 35,973 \\
\hline$R^{2}$ & 0.578 & 0.575 & 0.571 & 0.578 & 0.578 & 0.578 \\
\hline
\end{tabular}

Note: Column (1) reports the base parameter estimates corresponding to our preferred specification in Table 8. Columns (2) and (3) report estimates for households that experienced at least one income change of 10 percent (2) or 20 percent (3) in absolute value. In column (4) we add an indicator capturing the year when a household became unemployed. Column (5) adds an age interaction and column (6) adds an unemployment interaction with log income. 
Table 10: Sensitivity Analysis: Lags in AIDS Private-Label-Share System

\begin{tabular}{|c|c|c|c|c|c|}
\hline & $\begin{array}{c}\text { CPG } \\
\text { prices }+ \\
\text { proxies }\end{array}$ & $\begin{array}{c}1 \text { Income } \\
\text { Lag }\end{array}$ & $\begin{array}{c}2 \text { Income } \\
\text { Lags }\end{array}$ & $\begin{array}{c}3 \text { Income } \\
\text { Lags }\end{array}$ & $\begin{array}{c}4 \text { Income } \\
\text { Lags }\end{array}$ \\
\hline $\log$ (Income) & $\begin{array}{c}-0.38 \\
(0.0713)\end{array}$ & $\begin{array}{c}-0.349 \\
(0.0697)\end{array}$ & $\begin{array}{c}-0.372 \\
(0.0697)\end{array}$ & $\begin{array}{c}-0.346 \\
(0.0769)\end{array}$ & $\begin{array}{c}-0.282 \\
(0.0839)\end{array}$ \\
\hline $\log ($ Wealth$)$ & $\begin{array}{c}-0.16 \\
(0.164)\end{array}$ & $\begin{array}{l}-0.143 \\
(0.164)\end{array}$ & $\begin{array}{l}-0.133 \\
(0.164)\end{array}$ & $\begin{array}{r}-0.0325 \\
(0.182)\end{array}$ & $\begin{array}{l}0.0269 \\
(0.198)\end{array}$ \\
\hline $\mathbb{I}\{$ Unemployed $\}$ & $\begin{array}{c}0.353 \\
(0.0906)\end{array}$ & $\begin{array}{c}0.315 \\
(0.0906)\end{array}$ & $\begin{array}{c}0.284 \\
(0.091)\end{array}$ & $\begin{array}{c}0.317 \\
(0.102)\end{array}$ & $\begin{array}{c}0.372 \\
(0.113)\end{array}$ \\
\hline $\log (\text { Income })_{-1}$ & & $\begin{array}{c}-0.382 \\
(0.0725)\end{array}$ & $\begin{array}{c}-0.364 \\
(0.0712)\end{array}$ & $\begin{array}{l}-0.385 \\
(0.079)\end{array}$ & $\begin{array}{l}-0.438 \\
(0.088)\end{array}$ \\
\hline $\log (\text { Income })_{-2}$ & & & $\begin{array}{c}-0.3 \\
(0.072)\end{array}$ & $\begin{array}{c}-0.274 \\
(0.0791)\end{array}$ & $\begin{array}{c}-0.292 \\
(0.0853)\end{array}$ \\
\hline $\log (\text { Income })_{-3}$ & & & & $\begin{array}{c}-0.14 \\
(0.0796)\end{array}$ & $\begin{array}{l}-0.0984 \\
(0.0853)\end{array}$ \\
\hline $\log (\text { Income })_{-4}$ & & & & & $\begin{array}{c}-0.22 \\
(0.0844)\end{array}$ \\
\hline Trend & $\begin{array}{c}0.0368 \\
(0.00456)\end{array}$ & $\begin{array}{c}0.0369 \\
(0.00456)\end{array}$ & $\begin{array}{c}0.0375 \\
(0.00456)\end{array}$ & $\begin{array}{c}0.0353 \\
(0.00483)\end{array}$ & $\begin{array}{c}0.0433 \\
(0.00539)\end{array}$ \\
\hline $\mathbb{I}\{$ Recession $\}$ & $\begin{array}{c}0.138 \\
(0.0489)\end{array}$ & $\begin{array}{c}0.142 \\
(0.0489)\end{array}$ & $\begin{array}{c}0.145 \\
(0.0489)\end{array}$ & $\begin{array}{c}0.122 \\
(0.0587)\end{array}$ & $\begin{array}{c}0.264 \\
(0.0638)\end{array}$ \\
\hline $\mathbb{I}\{$ Post Recession $\}$ & $\begin{array}{c}0.24 \\
(0.111)\end{array}$ & $\begin{array}{c}0.224 \\
(0.111)\end{array}$ & $\begin{array}{c}0.221 \\
(0.111)\end{array}$ & $\begin{array}{l}0.245 \\
(0.12)\end{array}$ & $\begin{array}{c}0.186 \\
(0.129)\end{array}$ \\
\hline Trend $\times \mathbb{I}\{$ Recession $\}$ & $\begin{array}{c}0.011 \\
(0.00655)\end{array}$ & $\begin{array}{c}0.00984 \\
(0.00655)\end{array}$ & $\begin{array}{c}0.00953 \\
(0.00655)\end{array}$ & $\begin{array}{c}0.0106 \\
(0.00695)\end{array}$ & $\begin{array}{c}-0.0053 \\
(0.00778)\end{array}$ \\
\hline Trend $\times \mathbb{I}\{$ Post Rec. $\}$ & $\begin{array}{c}-0.0295 \\
(0.00578)\end{array}$ & $\begin{array}{c}-0.0299 \\
(0.00578)\end{array}$ & $\begin{array}{c}-0.0314 \\
(0.00579)\end{array}$ & $\begin{array}{c}-0.0316 \\
(0.00626)\end{array}$ & $\begin{array}{c}-0.0363 \\
(0.00676)\end{array}$ \\
\hline $\log$ (PI National Brand) & $\begin{array}{c}2.69 \\
(5.65)\end{array}$ & $\begin{array}{c}2.71 \\
(5.65)\end{array}$ & $\begin{array}{c}2.59 \\
(5.65)\end{array}$ & $\begin{array}{l}-0.922 \\
(6.16)\end{array}$ & $\begin{array}{l}-2.47 \\
(6.68)\end{array}$ \\
\hline $\log ($ PI Private Label $)$ & $\begin{array}{c}2.64 \\
(1.35)\end{array}$ & $\begin{array}{c}2.64 \\
(1.35)\end{array}$ & $\begin{array}{c}2.6 \\
(1.35)\end{array}$ & $\begin{array}{c}1.59 \\
(1.53)\end{array}$ & $\begin{array}{c}1.16 \\
(1.65)\end{array}$ \\
\hline $\log (\mathrm{PI}$ All CPG $)$ & $\begin{array}{l}0.843 \\
(5.94)\end{array}$ & $\begin{array}{c}0.92 \\
(5.94)\end{array}$ & $\begin{array}{c}1.08 \\
(5.94)\end{array}$ & $\begin{array}{l}5.72 \\
(6.5)\end{array}$ & $\begin{array}{c}7.14 \\
(7.04)\end{array}$ \\
\hline $\log (\mathrm{CPI})$ & $\begin{array}{l}0.511 \\
(1.01)\end{array}$ & $\begin{array}{l}0.559 \\
(1.01)\end{array}$ & $\begin{array}{l}0.542 \\
(1.01)\end{array}$ & $\begin{array}{l}0.734 \\
(1.09)\end{array}$ & $\begin{array}{l}-1.79 \\
(1.3)\end{array}$ \\
\hline $\log ($ PI Gen. Merchandise) & $\begin{array}{c}-2.21 \\
(0.667)\end{array}$ & $\begin{array}{c}-2.23 \\
(0.667)\end{array}$ & $\begin{array}{c}-2.25 \\
(0.667)\end{array}$ & $\begin{array}{c}-2.1 \\
(0.752)\end{array}$ & $\begin{array}{c}-2.1 \\
(0.83)\end{array}$ \\
\hline Fixed Effects & Hh. & Hh. & Hh. & Hh. & Hh. \\
\hline No. Obs. & $\begin{array}{l}1,317,596 \\
3,584926\end{array}$ & $1,317,596$ & $1,317,596$ & $\begin{array}{l}1,084,305 \\
3,818,217\end{array}$ & 899,423 \\
\hline $\begin{array}{l}\text { No. Missing } \\
\text { No. Clusters }\end{array}$ & $\begin{array}{c}3,584,926 \\
35,973\end{array}$ & $\begin{array}{c}3,584,926 \\
35,973\end{array}$ & $\begin{array}{c}3,584,926 \\
35,973\end{array}$ & $\begin{array}{c}3,818,217 \\
28,864\end{array}$ & $\begin{array}{c}4,003,099 \\
24,441\end{array}$ \\
\hline$R^{2}$ & 0.578 & 0.578 & 0.578 & 0.578 & 0.581 \\
\hline
\end{tabular}


Table 11: Income Effects Under Different Levels of Measurement Error in Income

\begin{tabular}{|c|c|c|c|c|c|c|}
\hline \multirow[t]{2}{*}{ Degree } & \multirow{2}{*}{$\frac{\sigma_{\omega}^{2}}{\sigma_{\log \left(I^{*}\right)}^{2}}$} & \multirow{2}{*}{$\frac{1}{1+\frac{\sigma_{\omega}^{2}}{\sigma_{\log \left(I^{*}\right)}^{2}}}$} & \multirow[t]{2}{*}{$\delta_{I}$} & \multicolumn{3}{|c|}{ Effect on PL Share } \\
\hline & & & & $I \downarrow 10 \%$ & $I \downarrow 25 \%$ & $I \downarrow 50 \%$ \\
\hline None & 0 & 1 & -0.38 & -0.04 & -0.10 & -0.19 \\
\hline Small & 0.5 & 0.67 & -0.57 & -0.06 & -0.14 & -0.29 \\
\hline Medium & 1 & 0.5 & -0.76 & -0.08 & -0.19 & -0.38 \\
\hline Large & 10 & 0.09 & -4.2 & -0.42 & -1.05 & -2.10 \\
\hline
\end{tabular}


Table 12: Upper Level Demand: CPG Expenditure System

\begin{tabular}{|c|c|c|c|c|}
\hline & $\begin{array}{c}\text { CPG } \\
\text { prices only }\end{array}$ & $\begin{array}{c}\text { CPG } \\
\text { prices }+ \\
\text { price } \\
\text { proxies }\end{array}$ & $\begin{array}{c}\text { CPG } \\
\text { prices }+ \\
\text { price } \\
\text { proxies }+ \\
\text { trend }\end{array}$ & $\begin{array}{c}\mathrm{CPG} \\
\text { prices }+ \\
\text { price } \\
\text { proxies }+ \\
\text { trend }+4 \\
\text { income } \\
\text { lags }\end{array}$ \\
\hline $\log ($ Income $)$ & $\begin{array}{c}0.0418 \\
(0.00812)\end{array}$ & $\begin{array}{c}0.0216 \\
(0.00825)\end{array}$ & $\begin{array}{c}0.0112 \\
(0.00928)\end{array}$ & $\begin{array}{l}0.00641 \\
(0.0112)\end{array}$ \\
\hline $\log ($ Wealth $)$ & $\begin{array}{c}0.0257 \\
(0.0039)\end{array}$ & $\begin{array}{c}0.0235 \\
(0.00389)\end{array}$ & $\begin{array}{c}0.0244 \\
(0.00387)\end{array}$ & $\begin{array}{c}0.025 \\
(0.00442)\end{array}$ \\
\hline $\mathbb{I}\{$ Unemployed $\}$ & $\begin{array}{c}-0.00221 \\
(0.005)\end{array}$ & $\begin{array}{l}-0.0026 \\
(0.005)\end{array}$ & $\begin{array}{l}-0.000319 \\
(0.00498)\end{array}$ & $\begin{array}{c}0.00915 \\
(0.00601)\end{array}$ \\
\hline $\log (\text { Income })_{-1}$ & & & & $\begin{array}{c}0.0453 \\
(0.00479)\end{array}$ \\
\hline $\log (\text { Income })_{-2}$ & & & & $\begin{array}{c}0.0315 \\
(0.00487)\end{array}$ \\
\hline $\log (\text { Income })_{-3}$ & & & & $\begin{array}{c}0.0178 \\
(0.00514)\end{array}$ \\
\hline $\log (\text { Income })_{-4}$ & & & & $\begin{array}{c}0.00447 \\
(0.00479)\end{array}$ \\
\hline $\log (\mathrm{PI}$ All CPG) & $\begin{array}{c}0.49 \\
(0.0289)\end{array}$ & $\begin{array}{c}0.802 \\
(0.0387)\end{array}$ & $\begin{array}{c}0.282 \\
(0.0556)\end{array}$ & $\begin{array}{c}0.309 \\
(0.0659)\end{array}$ \\
\hline $\log (\mathrm{CPI})$ & & $\begin{array}{c}0.0592 \\
(0.0324)\end{array}$ & $\begin{array}{c}-0.126 \\
(0.0349)\end{array}$ & $\begin{array}{c}-0.129 \\
(0.0423)\end{array}$ \\
\hline $\log ($ PI Gen. Merchandise $)$ & & $\begin{array}{c}-0.73 \\
(0.0463)\end{array}$ & $\begin{array}{c}-1.72 \\
(0.0612)\end{array}$ & $\begin{array}{c}-1.78 \\
(0.0775)\end{array}$ \\
\hline Trend & & & $\begin{array}{c}0.00608 \\
(0.000249)\end{array}$ & $\begin{array}{c}0.00592 \\
(0.000288)\end{array}$ \\
\hline $\mathbb{I}\{$ Recession $\}$ & & & $\begin{array}{c}0.0457 \\
(0.00279)\end{array}$ & $\begin{array}{c}0.043 \\
(0.00356)\end{array}$ \\
\hline $\mathbb{I}\{$ Post Recession $\}$ & & & $\begin{array}{c}-0.0913 \\
(0.00502)\end{array}$ & $\begin{array}{c}-0.0817 \\
(0.00578)\end{array}$ \\
\hline Trend $\times \mathbb{I}\{$ Recession $\}$ & & & $\begin{array}{c}-0.00647 \\
(0.000298)\end{array}$ & $\begin{array}{c}-0.00606 \\
(0.000357)\end{array}$ \\
\hline Trend $\times \mathbb{I}\{$ Post Rec. $\}$ & & & $\begin{array}{c}-0.00609 \\
(0.000318)\end{array}$ & $\begin{array}{c}-0.0056 \\
(0.000366)\end{array}$ \\
\hline Fixed Effects & Hh. & Hh. & Hh. & Hh. \\
\hline No. Obs. & $1,332,396$ & $1,314,940$ & $1,314,940$ & 897,747 \\
\hline No. Missing & $3,570,126$ & $3,587,582$ & $3,587,582$ & $4,004,775$ \\
\hline No. Clusters & 36,021 & 35,972 & 35,972 & 24,441 \\
\hline$R^{2}$ & 0.573 & 0.576 & 0.576 & 0.582 \\
\hline
\end{tabular}


Table 13: Income and Wealth Elasticities of Private-Label Demand

\begin{tabular}{|c|c|c|c|}
\hline & $\begin{array}{l}\text { PL share } \\
\text { elasticity }\end{array}$ & $\begin{array}{c}\text { CPG } \\
\text { expenditure } \\
\text { elasticity }\end{array}$ & $\begin{array}{c}\text { Total } \\
\text { elasticity }\end{array}$ \\
\hline \multicolumn{4}{|c|}{ Income Elasticity: Contemporaneous Income } \\
\hline & -0.0204 & 0.0244 & 0.0040 \\
\hline & 0.0038 & 0.0039 & 0.0054 \\
\hline \multicolumn{4}{|c|}{ Income Elasticity: Permanent Income } \\
\hline & -0.0714 & 0.1240 & 0.0527 \\
\hline & 0.0433 & 0.0489 & 0.0654 \\
\hline \multicolumn{4}{|c|}{ Wealth Elasticity } \\
\hline & -0.0086 & 0.0112 & 0.0026 \\
\hline & 0.0088 & 0.0093 & 0.0128 \\
\hline
\end{tabular}


2006

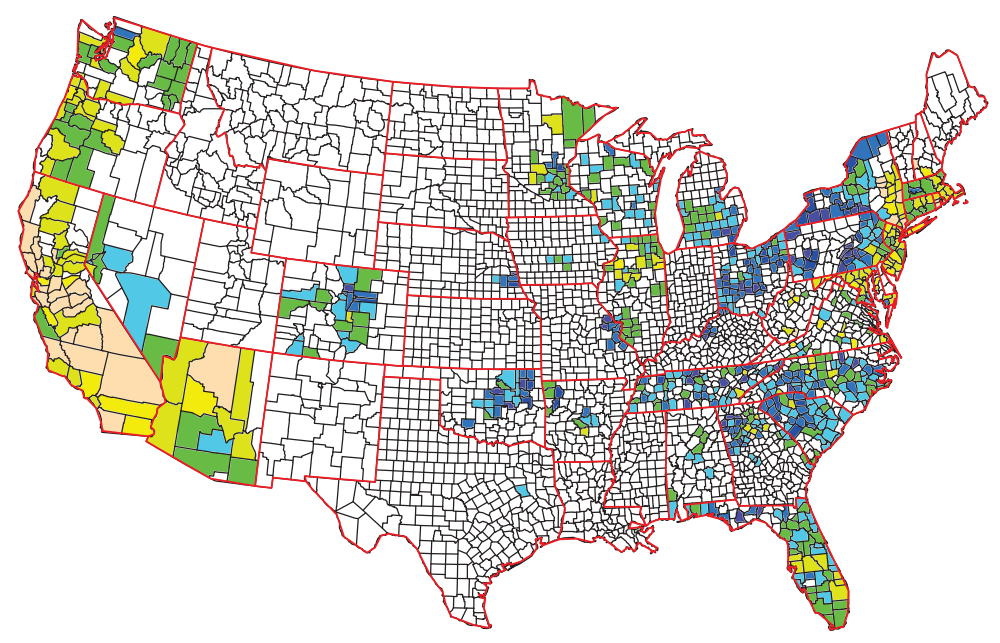

2009

$\square<90$
$\square 90-106$
$\square 106-141$
$\square 141-212$
$\square 212-313$
$\square 313-468$
$\square 468-553$
$\square>553$

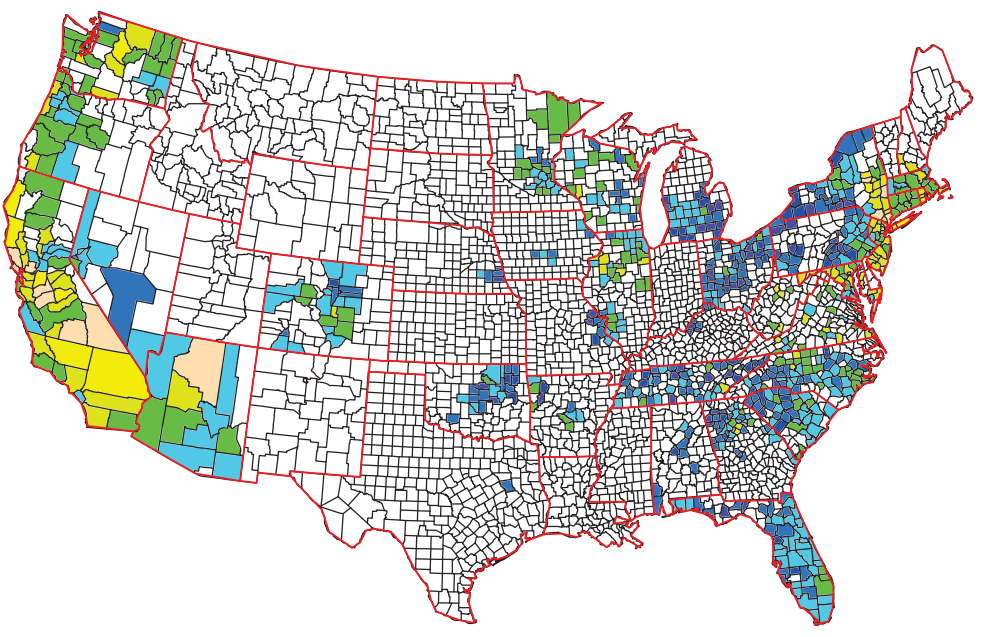

Figure 1: Zillow Home Value Index by ZIP Code, 2009 vs. 2006 


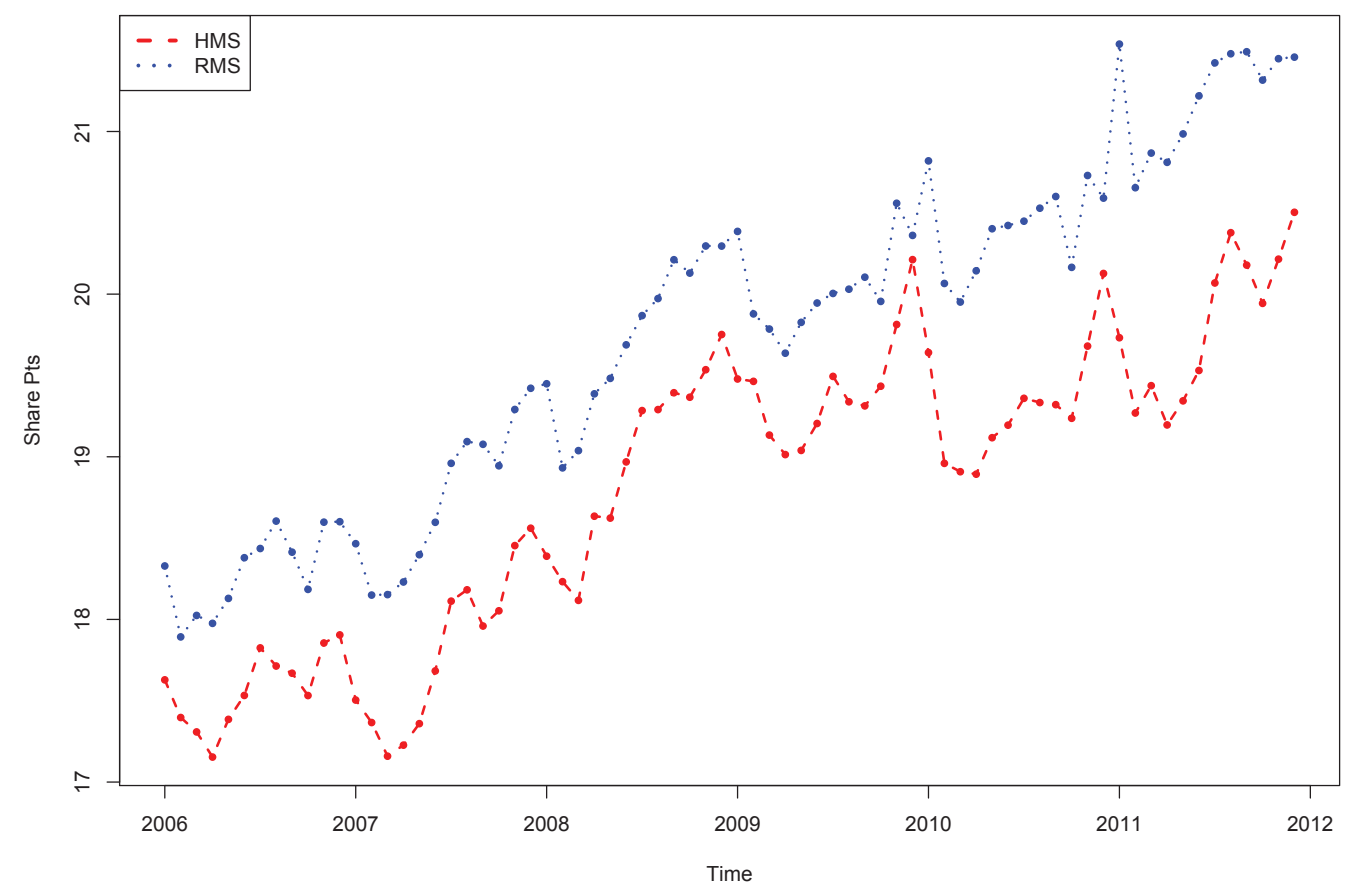

Figure 2: Comparison of Private-Label Share: Homescan vs. RMS Data 

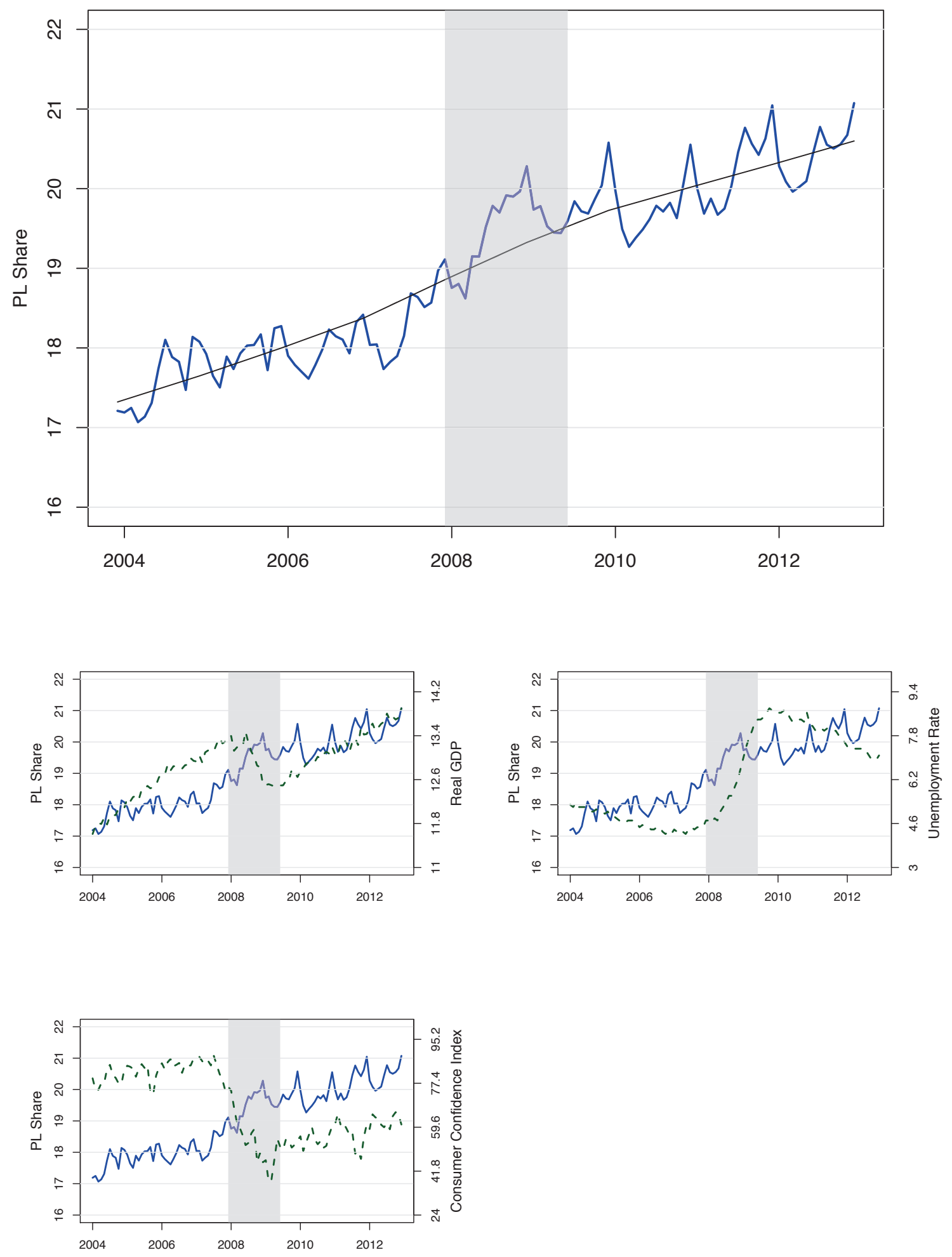

Figure 3: Private-Label Share, 2004-2012, and Macroeconomic Factors 
2006

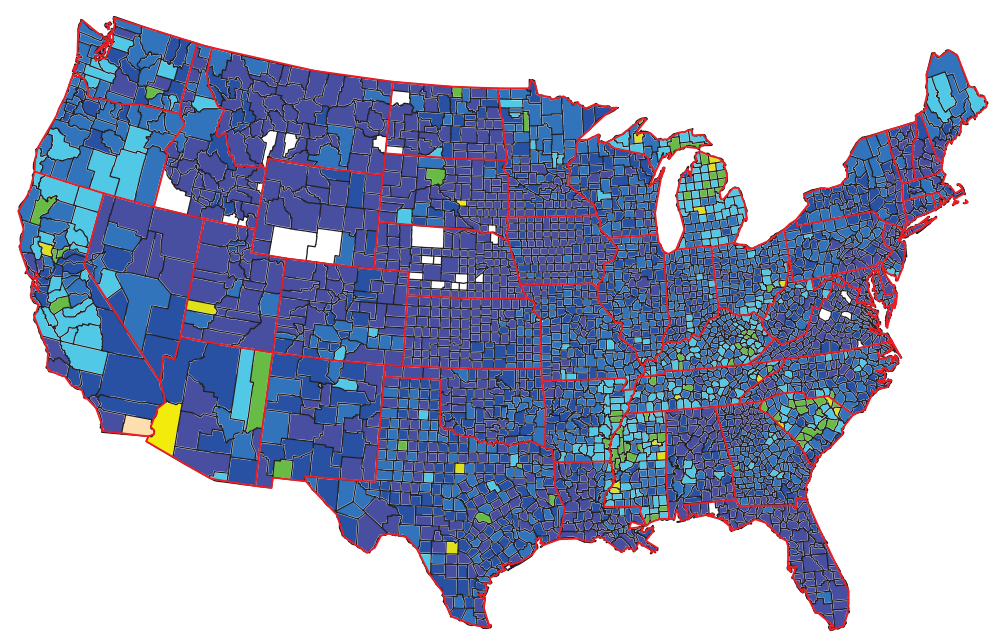

2009

$\begin{array}{ll}\square<4 \\ \square & 4-5 \\ \square & 5-7 \\ \square & 7-9 \\ \square & 9-11 \\ \square & 11-13 \\ \square & 13-15 \\ \square>15\end{array}$

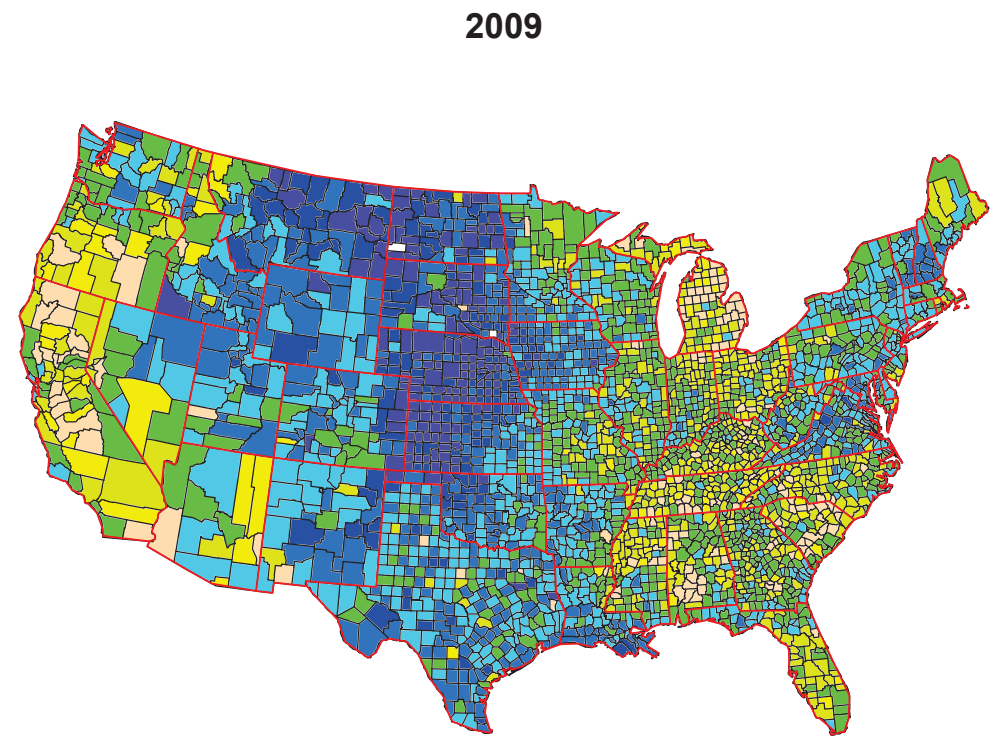

Figure 4: Unemployment Rate by FIPS County, 2009 vs. 2006 

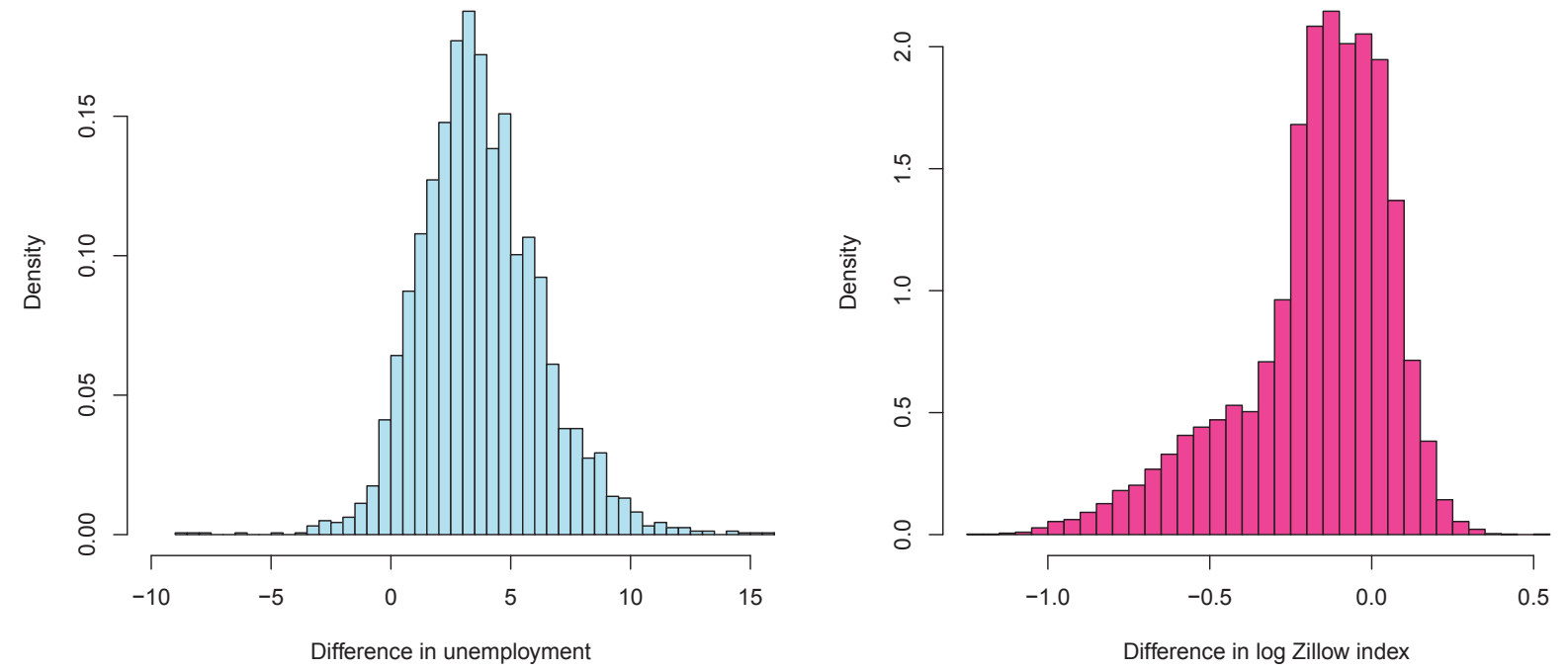

Figure 5: Cross-Sectional Differences in Unemployment Rates (FIPS County Code) and (log) Zillow Home Values (ZIP Code), December 2009 vs. January 2006 




Figure 6: Regional National-Brand/Private-Label Price Changes

Note: The panels show yearly log changes in the relative national-brand/private-label price index, $\log \left(P_{N B, t} / P_{P L, t}\right)-\log \left(P_{N B, t-1} / P_{P L, t-1}\right)$, between year $t-1$ and year $t$. The observations are at the DMA level, and the regional price indices are constructed using regional category expenditure weights. 

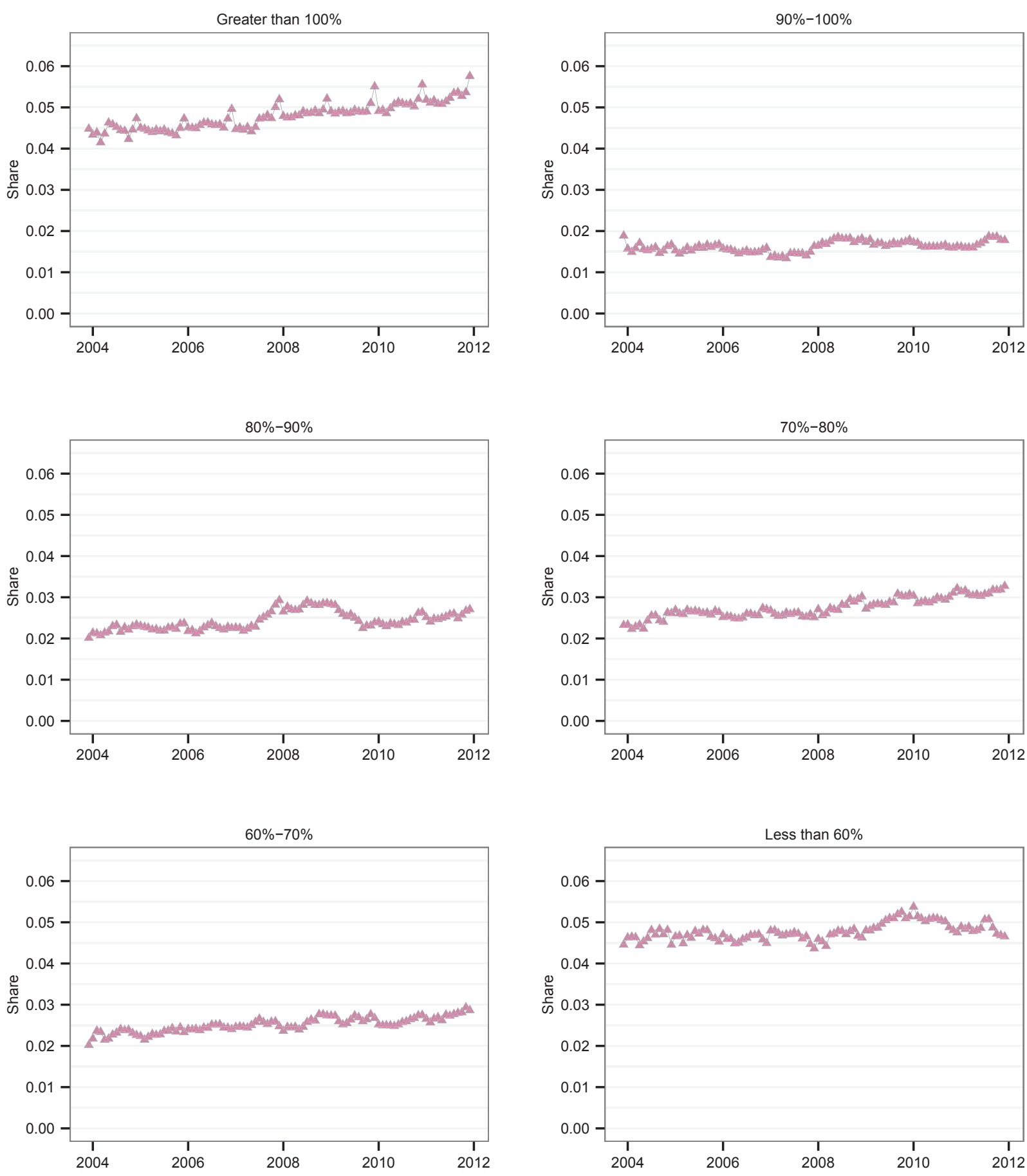

Figure 7: Private-Label Share by Quality Tier

Note: The graph displays the private-label expenditure share for six distinct quality tiers. The tiers are defined based on the relative price of product $j$ in period $t$. The lowest quality tier includes products such that $r_{j t}<0.6$, the second lowest quality tier includes products such that $0.6 \leq r_{j t}<0.7$, etc. 


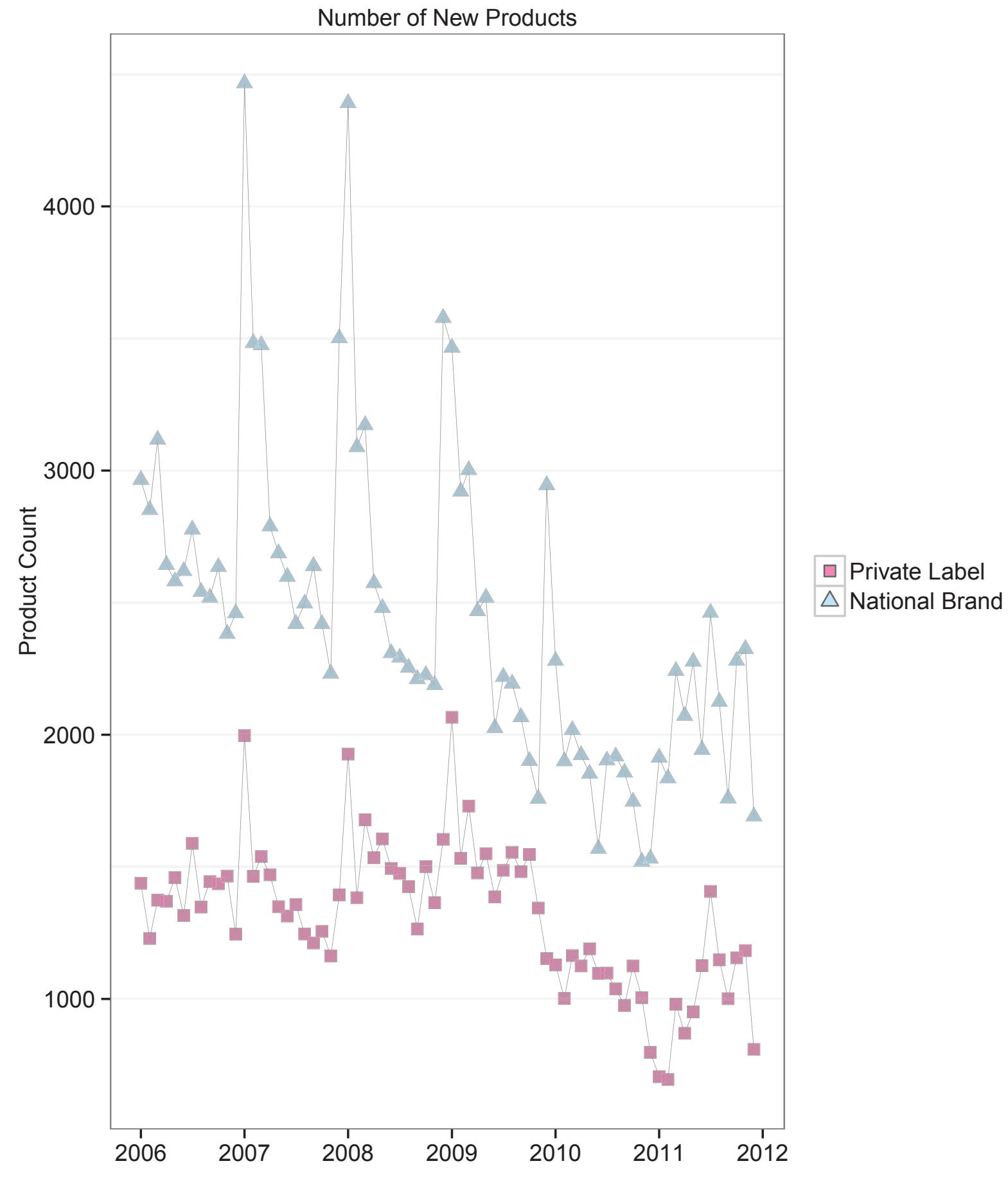

Figure 8: New Private-Label and National-Brand Product Introductions 

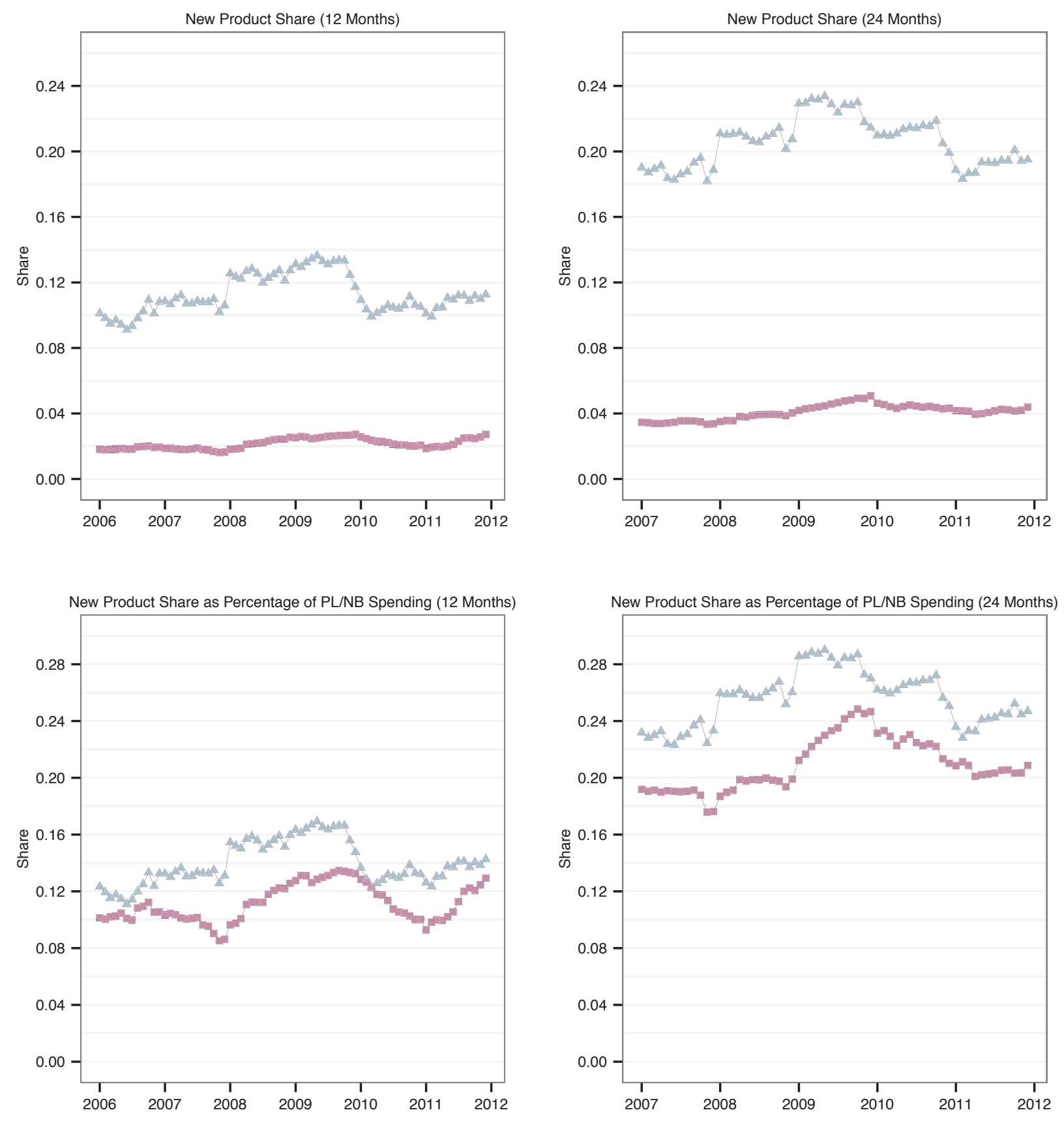

Private Label $\triangle$ National Brand

Figure 9: Shares for New Private-Label and National-Brand Products

Note: The two panels in the top row show the CPG expenditure share for private-label and national-brand products introduced within the last 12 or 24 months. The panels in the bottomrow show the new private-label share expressed as a percentage of total spending on private-label products only, and the new national-brand share expressed as a percentage of total spending on national brands only. 

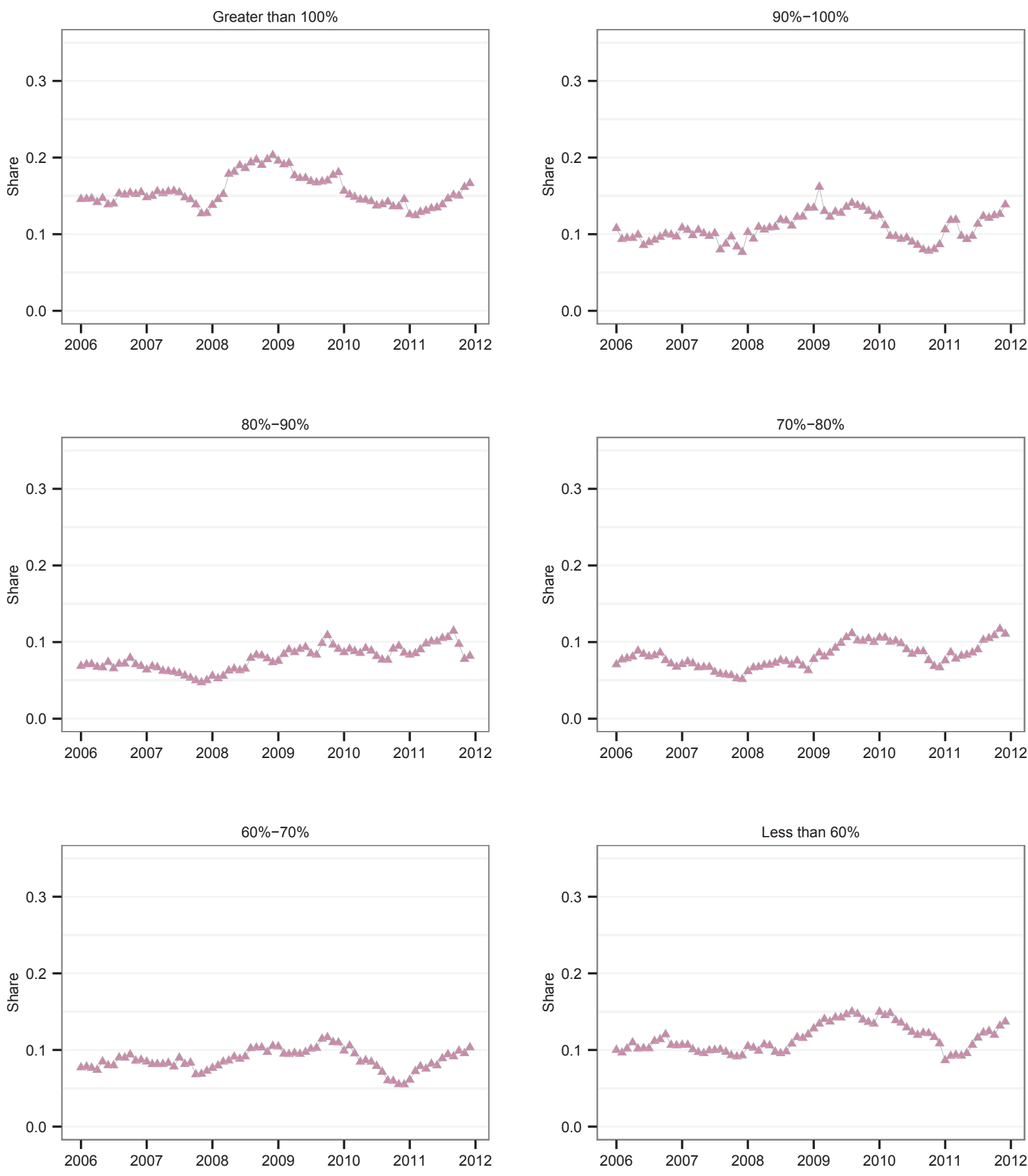

Figure 10: Share of New Products Within Each Quality Tier (12 Months)

Note: The graph shows the new private-label product share as a percentage of total spending within each of the six distinct quality tiers. New products include all products introduced within the last 12 months. 


\section{Appendices}

\section{A Price index construction}

To estimate the private-label expenditure share equation (5) we need to construct price indices. Using the Homescan data to construct these indices is difficult because we only observe prices conditional on a household purchase. Correspondingly, the price observations for any given product in a store are sparse, and the sampled prices do not reflect the true price levels that households face because a purchase is more likely at a relatively low, possibly promoted price. Instead, we calculate the price indices using price observations from the Nielsen RMS (Retail Management System) scanner data. The price series in the RMS data are much less sparse because prices are recorded in any given week whenever at least one unit of a product is sold. For weeks when the sales quantity is zero we impute the shelf price as the most recent base (non-promoted) price, which we predict using an algorithm that we developed to classify prices as base or promoted prices. Since our store sample does not include all stores, excluding for instance Walmart, we cannot construct the exact price indices corresponding to each household's purchase basket. Instead, we first calculate regional category-level price indices. We then calculate household-level price indices by aggregating over the category-level indices using household-level category expenditure weights.

The first step is to calculate store-level category price indices. We index stores by $s$ and categories by $k$. The category $k$ price index $\pi_{k s t}$ is then defined as a weighted geometric average:

$$
\frac{\pi_{k s t}}{\pi_{k s, t-1}}=\prod_{j \in \mathcal{J}_{k s t}}\left(\frac{p_{j s t}}{p_{j s, t-1}}\right)^{\omega_{j r}}
$$

$\mathcal{J}_{k s t}$ is the set of products in category $k$ and store $s$ that are available at time $t$ and $t-1$, and $p_{j s t}$ in the price of product $j \in \mathcal{J}_{k s t}$. $\omega_{j r}$ is the average expenditure share of product $j$ in the region $r$ where the store is located. ${ }^{22}$

In the second step we calculate regional category price indices $\hat{\pi}_{k r t}$ :

$$
\frac{\hat{\pi}_{k r t}}{\hat{\pi}_{k r, t-1}}=\prod_{s \in \mathcal{S}_{k r t}}\left(\frac{\pi_{k s t}}{\pi_{k s, t-1}}\right)^{\omega_{s r}} .
$$

$\mathcal{S}_{k r t}$ is the set of stores carrying products in category $k$ in region $r$, and $\omega_{s r}$ is a store size weight based on the total average weekly revenue (across all categories) in store $s .^{23}$ We choose the 205 DMA's in our sample as regions. We make this choice to balance the competing goals of (i) ensuring that the regional price indices are based on a sufficient number and variety of stores and (ii) allowing for sufficient price variation across local regions.

\footnotetext{
${ }^{22}$ In general, not all products are sold in store $s$ at time $t$ and $t-1$, and hence the weights $\omega_{j r}$ are renormalized to sum to one. Therefore, to be entirely concise, the weights should be indexed as $\omega_{j k s t}$.

${ }^{23}$ Like the product weights, the store size weights are renormalized to sum to one.
} 
In the third step we then calculate household-specific price indices $P_{h t}$ :

$$
\frac{P_{h t}}{P_{h, t-1}}=\prod_{k \in \mathcal{I}_{h}}\left(\frac{\hat{\pi}_{k r t}}{\hat{\pi}_{k r, t-1}}\right)^{\omega_{k h}} .
$$

$\mathcal{I}_{h}$ is the set of categories in which household $h$ ever purchases and $\omega_{k h}$ is a household-specific category expenditure weight. Note that $P_{h t}$ is customized to reflect the spending patterns of household $h$ across product categories based on region-specific, not household-specific category price levels.

We create versions of $P_{h t}$ for all CPG products and separately for national-brand and privatelabel products. We also use data on purchases in the "General Merchandise" department, which we do not include in the definition of CPG products, to create an upper level price index for the General Merchandise product group. Finally, we proxy for a product group including all other items using the regional consumer price index (CPI) from the Bureau of Labor Statistics. The CPI is a geometric-weight price index and hence approximately satisfies

$$
\log \left(P_{C P I}\right)=\omega_{1} \log \left(P_{1}\right)+\omega_{2} \log \left(P_{2}\right)+\omega_{3} \log \left(P_{3}\right)
$$

where 1 is an index for the CPG product group, 2 is an index for the General Merchandise product group, and 3 represents the product group of "all other" items. Hence, $\log \left(P_{3}\right)$ can be represented as a linear combination of the log of the CPI and the log of the CPG and General Merchandise price indices. We can therefore include the log CPI instead of the "all other" product group price index in the upper level demand model and the private-label share equation, although this will change the interpretation of the estimated price index parameters.

\section{B Additional Lower-Level Demand Estimates}

In this appendix, we provide our lower-level demand model estimated with prices indices that have fixed regional weights (as opposed to the household-specific weights used above). We also provide estimate of the lower-level demand for food products only. 
Table 14: Lower Level Demand: AIDS Private-Label-Share System (Food Only)

\begin{tabular}{|c|c|c|c|}
\hline & $\begin{array}{c}\text { within }+ \\
\text { recession } \\
+ \text { trend }\end{array}$ & $\begin{array}{l}\mathrm{CPG} \\
\text { prices }\end{array}$ & $\begin{array}{c}\text { CPG } \\
\text { prices }+ \\
\text { proxies }\end{array}$ \\
\hline $\log$ (Income) & $\begin{array}{l}-0.361 \\
(0.072)\end{array}$ & $\begin{array}{c}-0.317 \\
(0.0781)\end{array}$ & $\begin{array}{c}-0.316 \\
(0.0778)\end{array}$ \\
\hline $\log ($ Wealth$)$ & $\begin{array}{l}-0.755 \\
(0.157)\end{array}$ & $\begin{array}{l}-0.264 \\
(0.184)\end{array}$ & $\begin{array}{l}-0.254 \\
(0.184)\end{array}$ \\
\hline $\mathbb{I}\{$ Unemployed $\}$ & $\begin{array}{c}0.341 \\
(0.0908)\end{array}$ & $\begin{array}{c}0.282 \\
(0.0996)\end{array}$ & $\begin{array}{c}0.288 \\
(0.0999)\end{array}$ \\
\hline Trend & $\begin{array}{c}0.0338 \\
(0.00182)\end{array}$ & $\begin{array}{c}0.0217 \\
(0.00433)\end{array}$ & $\begin{array}{c}0.0296 \\
(0.00489)\end{array}$ \\
\hline $\mathbb{I}\{$ Recession $\}$ & $\begin{array}{c}0.39 \\
(0.0477)\end{array}$ & $\begin{array}{c}-0.009 \\
(0.0527)\end{array}$ & $\begin{array}{l}0.00379 \\
(0.0552)\end{array}$ \\
\hline $\mathbb{I}\{$ Post Recession $\}$ & $\begin{array}{c}0.183 \\
(0.0865)\end{array}$ & $\begin{array}{l}-0.308 \\
(0.104)\end{array}$ & $\begin{array}{l}-0.411 \\
(0.107)\end{array}$ \\
\hline Trend $\times \mathbb{I}\{$ Recession $\}$ & $\begin{array}{c}0.00538 \\
(0.00471)\end{array}$ & $\begin{array}{c}-0.018 \\
(0.0055)\end{array}$ & $\begin{array}{c}-0.0242 \\
(0.00624)\end{array}$ \\
\hline Trend $\times \mathbb{I}\{$ Post Rec. $\}$ & $\begin{array}{c}-0.0241 \\
(0.00433)\end{array}$ & $\begin{array}{c}-0.00247 \\
(0.00597)\end{array}$ & $\begin{array}{c}-0.0139 \\
(0.00645)\end{array}$ \\
\hline $\log ($ PI National Brand $)$ & & $\begin{array}{c}14.7 \\
(2.36)\end{array}$ & $\begin{array}{c}15.1 \\
(2.39)\end{array}$ \\
\hline $\log ($ PI Private Label) & & $\begin{array}{l}0.739 \\
(1.27)\end{array}$ & $\begin{array}{l}0.439 \\
(1.26)\end{array}$ \\
\hline $\log (\mathrm{PI}$ All CPG $)$ & & $\begin{array}{l}-2.34 \\
(2.43)\end{array}$ & $\begin{array}{l}-2.11 \\
(2.49)\end{array}$ \\
\hline $\log (\mathrm{CPI})$ & & & $\begin{array}{l}-2.12 \\
(1.11)\end{array}$ \\
\hline $\log$ (PI Gen. Merchandise) & & & $\begin{array}{c}-2.84 \\
(0.759)\end{array}$ \\
\hline Fixed Effects & $\mathrm{HH}$ & $\mathrm{HH}$ & $\mathrm{HH}$ \\
\hline No. Obs. & $1,716,947$ & $1,335,083$ & $1,317,535$ \\
\hline No. Missing & $3,185,575$ & $3,567,439$ & $3,584,987$ \\
\hline No. Clusters & 39,413 & 36,021 & 35,972 \\
\hline$R^{2}$ & 0.576 & 0.583 & 0.585 \\
\hline
\end{tabular}


Table 15: Upper Level Demand: CPG Expenditure System (food only)

\begin{tabular}{|c|c|c|c|c|}
\hline & $\begin{array}{c}\text { CPG } \\
\text { prices } \\
\text { only }\end{array}$ & $\begin{array}{c}\mathrm{CPG} \\
\text { prices }+ \\
\text { price } \\
\text { proxies }\end{array}$ & $\begin{array}{c}\mathrm{CPG} \\
\text { prices }+ \\
\text { price } \\
\text { proxies }+ \\
\text { trend }\end{array}$ & $\begin{array}{c}\mathrm{CPG} \\
\text { prices }+ \\
\text { price } \\
\text { proxies }+ \\
\text { trend }+4 \\
\text { income } \\
\text { lags }\end{array}$ \\
\hline $\log$ (Income) & $\begin{array}{c}0.0258 \\
(0.0039)\end{array}$ & $\begin{array}{c}0.0236 \\
(0.00389)\end{array}$ & $\begin{array}{c}0.0244 \\
(0.00387)\end{array}$ & $\begin{array}{c}0.025 \\
(0.00442)\end{array}$ \\
\hline $\log ($ Wealth $)$ & $\begin{array}{c}0.0433 \\
(0.00812)\end{array}$ & $\begin{array}{c}0.0227 \\
(0.00825)\end{array}$ & $\begin{array}{c}0.0111 \\
(0.00928)\end{array}$ & $\begin{array}{l}0.00632 \\
(0.0112)\end{array}$ \\
\hline $\mathbb{I}\{$ Unemployed $\}$ & $\begin{array}{c}-0.00216 \\
(0.005)\end{array}$ & $\begin{array}{c}-0.00253 \\
(0.005)\end{array}$ & $\begin{array}{l}-0.00033 \\
(0.00498)\end{array}$ & $\begin{array}{c}0.00915 \\
(0.00601)\end{array}$ \\
\hline $\log (\text { Income })_{-1}$ & & & & $\begin{array}{c}0.0453 \\
(0.00479)\end{array}$ \\
\hline $\log (\text { Income })_{-2}$ & & & & $\begin{array}{c}0.0315 \\
(0.00487)\end{array}$ \\
\hline 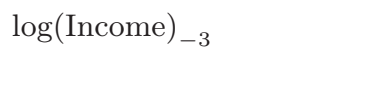 & & & & $\begin{array}{c}0.0178 \\
(0.00514)\end{array}$ \\
\hline $\log (\text { Income })_{-4}$ & & & & $\begin{array}{c}0.00448 \\
(0.00479)\end{array}$ \\
\hline $\log (\mathrm{PI}$ All CPG $)$ & $\begin{array}{c}0.535 \\
(0.0307)\end{array}$ & $\begin{array}{c}0.906 \\
(0.0411)\end{array}$ & $\begin{array}{c}0.319 \\
(0.0609)\end{array}$ & $\begin{array}{c}0.352 \\
(0.0725)\end{array}$ \\
\hline $\log (\mathrm{PI}$ Gen. Merchandise $)$ & & $\begin{array}{c}0.0494 \\
(0.0324)\end{array}$ & $\begin{array}{c}-0.126 \\
(0.0349)\end{array}$ & $\begin{array}{c}-0.13 \\
(0.0423)\end{array}$ \\
\hline $\log (\mathrm{CPI})$ & & $\begin{array}{c}-0.782 \\
(0.0463)\end{array}$ & $\begin{array}{c}-1.72 \\
(0.0613)\end{array}$ & $\begin{array}{c}-1.78 \\
(0.0776)\end{array}$ \\
\hline Trend & & & $\begin{array}{c}0.00602 \\
(0.000253)\end{array}$ & $\begin{array}{c}0.00585 \\
(0.000293)\end{array}$ \\
\hline $\mathbb{I}\{$ Recession $\}$ & & & $\begin{array}{c}0.0456 \\
(0.0028)\end{array}$ & $\begin{array}{c}0.0428 \\
(0.00356)\end{array}$ \\
\hline $\mathbb{I}\{$ Post Recession $\}$ & & & $\begin{array}{c}-0.0908 \\
(0.00502)\end{array}$ & $\begin{array}{c}-0.0809 \\
(0.00579)\end{array}$ \\
\hline Trend $\times \mathbb{I}\{$ Recession $\}$ & & & $\begin{array}{c}-0.00645 \\
(0.000298)\end{array}$ & $\begin{array}{c}-0.00603 \\
(0.000356)\end{array}$ \\
\hline Trend $\times \mathbb{I}\{$ Post Rec. $\}$ & & & $\begin{array}{c}-0.00602 \\
(0.000322)\end{array}$ & $\begin{array}{c}-0.00552 \\
(0.000371)\end{array}$ \\
\hline Fixed Effects & $\mathrm{HH}$ & $\mathrm{HH}$ & $\mathrm{HH}$ & $\mathrm{HH}$ \\
\hline No. Obs. & $1,332,396$ & $1,314,940$ & $1,314,940$ & 897,747 \\
\hline No. Missing & $3,570,126$ & $3,587,582$ & $3,587,582$ & $4,004,775$ \\
\hline No. Clusters & 36,021 & 35,972 & 35,972 & 24,441 \\
\hline$R^{2}$ & 0.573 & 0.576 & 0.576 & 0.582 \\
\hline
\end{tabular}


Table 16: Lower Level Demand: AIDS Private-Label-Share System (Region Weighted Price Index)

\begin{tabular}{|c|c|c|c|}
\hline & $\begin{array}{c}\text { within }+ \\
\text { recession } \\
+ \text { trend }\end{array}$ & $\begin{array}{l}\mathrm{CPG} \\
\text { prices }\end{array}$ & $\begin{array}{c}\mathrm{CPG} \\
\text { prices }+ \\
\text { proxies }\end{array}$ \\
\hline $\log ($ Income $)$ & $\begin{array}{c}-0.412 \\
(0.0654)\end{array}$ & $\begin{array}{c}-0.376 \\
(0.0717)\end{array}$ & $\begin{array}{c}-0.382 \\
(0.0712)\end{array}$ \\
\hline $\log ($ Wealth$)$ & $\begin{array}{l}-0.545 \\
(0.141)\end{array}$ & $\begin{array}{l}-0.162 \\
(0.164)\end{array}$ & $\begin{array}{l}-0.202 \\
(0.164)\end{array}$ \\
\hline $\mathbb{I}\{$ Unemployed $\}$ & $\begin{array}{c}0.373 \\
(0.0812)\end{array}$ & $\begin{array}{c}0.34 \\
(0.0905)\end{array}$ & $\begin{array}{c}0.352 \\
(0.0907)\end{array}$ \\
\hline Trend & $\begin{array}{c}0.0372 \\
(0.00159)\end{array}$ & $\begin{array}{c}0.0415 \\
(0.00467)\end{array}$ & $\begin{array}{c}0.0518 \\
(0.00514)\end{array}$ \\
\hline $\mathbb{I}\{$ Recession $\}$ & $\begin{array}{c}0.322 \\
(0.0427)\end{array}$ & $\begin{array}{c}0.202 \\
(0.0465)\end{array}$ & $\begin{array}{c}0.123 \\
(0.0499)\end{array}$ \\
\hline $\mathbb{I}\{$ Post Recession $\}$ & $\begin{array}{c}0.479 \\
(0.0769)\end{array}$ & $\begin{array}{c}0.202 \\
(0.117)\end{array}$ & $\begin{array}{l}0.0553 \\
(0.122)\end{array}$ \\
\hline Trend $\times \mathbb{I}\{$ Recession $\}$ & $\begin{array}{c}0.019 \\
(0.00419)\end{array}$ & $\begin{array}{c}0.00591 \\
(0.00648)\end{array}$ & $\begin{array}{c}0.00602 \\
(0.00733)\end{array}$ \\
\hline Trend $\times \mathbb{I}\{$ Post Rec. $\}$ & $\begin{array}{c}-0.029 \\
(0.0039)\end{array}$ & $\begin{array}{c}-0.0277 \\
(0.00586)\end{array}$ & $\begin{array}{c}-0.0601 \\
(0.00681)\end{array}$ \\
\hline $\log ($ PI National Brand) & & $\begin{array}{c}9.99 \\
(7.09)\end{array}$ & $\begin{array}{c}10.8 \\
(7.18)\end{array}$ \\
\hline $\log ($ PI Private Label) & & $\begin{array}{c}5.7 \\
(2.37)\end{array}$ & $\begin{array}{c}4.86 \\
(2.37)\end{array}$ \\
\hline $\log ($ PI All CPG) & & $\begin{array}{l}-10.6 \\
(8.23)\end{array}$ & $\begin{array}{l}-9.83 \\
(8.29)\end{array}$ \\
\hline $\log (\mathrm{CPI})$ & & & $\begin{array}{l}-1.53 \\
(1.03)\end{array}$ \\
\hline $\log$ (PI Gen. Merchandise) & & & $\begin{array}{l}-10.7 \\
(1.18)\end{array}$ \\
\hline Fixed Effects & $\mathrm{HH}$ & $\mathrm{HH}$ & $\mathrm{HH}$ \\
\hline No. Obs. & $1,716,947$ & $1,335,207$ & $1,317,596$ \\
\hline No. Missing & $3,185,575$ & $3,567,315$ & $3,584,926$ \\
\hline No. Clusters & 39,413 & 36,022 & 35,973 \\
\hline$R^{2}$ & 0.57 & 0.576 & 0.578 \\
\hline
\end{tabular}


Table 17: Upper Level Demand: CPG Expenditure System (Region Weighted Price Index)

\begin{tabular}{|c|c|c|c|c|}
\hline & $\begin{array}{l}\text { CPG } \\
\text { prices } \\
\text { only }\end{array}$ & $\begin{array}{c}\mathrm{CPG} \\
\text { prices }+ \\
\text { price } \\
\text { proxies }\end{array}$ & $\begin{array}{c}\mathrm{CPG} \\
\text { prices }+ \\
\text { price } \\
\text { proxies }+ \\
\text { trend }\end{array}$ & $\begin{array}{c}\mathrm{CPG} \\
\text { prices }+ \\
\text { price } \\
\text { proxies }+ \\
\text { trend }+4 \\
\text { income } \\
\text { lags }\end{array}$ \\
\hline $\log$ (Income) & $\begin{array}{c}0.0283 \\
(0.0037)\end{array}$ & $\begin{array}{c}0.0267 \\
(0.00369)\end{array}$ & $\begin{array}{c}0.0266 \\
(0.00369)\end{array}$ & $\begin{array}{c}0.0238 \\
(0.0042)\end{array}$ \\
\hline $\log ($ Wealth $)$ & $\begin{array}{c}0.0601 \\
(0.00794)\end{array}$ & $\begin{array}{c}0.0444 \\
(0.00807)\end{array}$ & $\begin{array}{c}0.0156 \\
(0.00895)\end{array}$ & $\begin{array}{l}0.00942 \\
(0.0107)\end{array}$ \\
\hline $\mathbb{I}\{$ Unemployed $\}$ & $\begin{array}{l}-0.00512 \\
(0.00465)\end{array}$ & $\begin{array}{l}-0.00442 \\
(0.00462)\end{array}$ & $\begin{array}{r}-0.00277 \\
(0.0046)\end{array}$ & $\begin{array}{c}0.0083 \\
(0.0056)\end{array}$ \\
\hline $\log (\text { Income })_{-1}$ & & & & $\begin{array}{c}0.0451 \\
(0.00438)\end{array}$ \\
\hline $\log (\text { Income })_{-2}$ & & & & $\begin{array}{c}0.0333 \\
(0.00446)\end{array}$ \\
\hline $\log (\text { Income })_{-3}$ & & & & $\begin{array}{c}0.0166 \\
(0.00454)\end{array}$ \\
\hline $\log (\text { Income })_{-4}$ & & & & $\begin{array}{c}0.00406 \\
(0.00445)\end{array}$ \\
\hline $\log (\mathrm{PI}$ All CPG) & $\begin{array}{c}0.41 \\
(0.0303)\end{array}$ & $\begin{array}{c}1.04 \\
(0.0435)\end{array}$ & $\begin{array}{c}0.528 \\
(0.074)\end{array}$ & $\begin{array}{c}0.627 \\
(0.0876)\end{array}$ \\
\hline $\log$ (PI Gen. Merchandise) & & $\begin{array}{c}0.075 \\
(0.0481)\end{array}$ & $\begin{array}{c}-0.495 \\
(0.0585)\end{array}$ & $\begin{array}{c}-0.54 \\
(0.068)\end{array}$ \\
\hline $\log (\mathrm{CPI})$ & & $\begin{array}{l}-1.08 \\
(0.045)\end{array}$ & $\begin{array}{c}-1.73 \\
(0.0593)\end{array}$ & $\begin{array}{c}-1.77 \\
(0.0735)\end{array}$ \\
\hline Trend & & & $\begin{array}{c}0.00478 \\
(0.00026)\end{array}$ & $\begin{array}{c}0.00451 \\
(0.000301)\end{array}$ \\
\hline $\mathbb{I}\{$ Recession $\}$ & & & $\begin{array}{c}0.0445 \\
(0.00269)\end{array}$ & $\begin{array}{c}0.0387 \\
(0.00344)\end{array}$ \\
\hline $\mathbb{I}\{$ Post Recession $\}$ & & & $\begin{array}{c}-0.0702 \\
(0.00478)\end{array}$ & $\begin{array}{l}-0.0627 \\
(0.0055)\end{array}$ \\
\hline Trend $\times \mathbb{I}\{$ Recession $\}$ & & & $\begin{array}{c}-0.00598 \\
(0.000284)\end{array}$ & $\begin{array}{c}-0.00542 \\
(0.000336)\end{array}$ \\
\hline Trend $\times \mathbb{I}\{$ Post Rec. $\}$ & & & $\begin{array}{c}-0.00633 \\
(0.000353)\end{array}$ & $\begin{array}{c}-0.00576 \\
(0.000405)\end{array}$ \\
\hline Fixed Effects & $\mathrm{HH}$ & $\mathrm{HH}$ & $\mathrm{HH}$ & $\mathrm{HH}$ \\
\hline No. Obs. & $1,334,612$ & $1,317,015$ & $1,317,015$ & 899,050 \\
\hline No. Missing & $3,567,910$ & $3,585,507$ & $3,585,507$ & $4,003,472$ \\
\hline No. Clusters & 36,022 & 35,973 & 35,973 & 24,441 \\
\hline$R^{2}$ & 0.578 & 0.58 & 0.581 & 0.586 \\
\hline
\end{tabular}


Table 18: Lower Level Demand: AIDS Private-Label-Share System (Food Only and Region Weighted Price Index)

\begin{tabular}{|c|c|c|c|}
\hline & $\begin{array}{c}\text { within }+ \\
\text { recession } \\
+ \text { trend }\end{array}$ & $\begin{array}{l}\mathrm{CPG} \\
\text { prices }\end{array}$ & $\begin{array}{c}\text { CPG } \\
\text { prices }+ \\
\text { proxies }\end{array}$ \\
\hline $\log ($ Income $)$ & $\begin{array}{l}-0.361 \\
(0.072)\end{array}$ & $\begin{array}{l}-0.314 \\
(0.078)\end{array}$ & $\begin{array}{c}-0.316 \\
(0.0777)\end{array}$ \\
\hline $\log$ (Wealth) & $\begin{array}{l}-0.755 \\
(0.157)\end{array}$ & $\begin{array}{l}-0.233 \\
(0.184)\end{array}$ & $\begin{array}{l}-0.262 \\
(0.184)\end{array}$ \\
\hline $\mathbb{I}\{$ Unemployed $\}$ & $\begin{array}{c}0.341 \\
(0.0908)\end{array}$ & $\begin{array}{c}0.282 \\
(0.0995)\end{array}$ & $\begin{array}{c}0.287 \\
(0.0999)\end{array}$ \\
\hline Trend & $\begin{array}{c}0.0338 \\
(0.00182)\end{array}$ & $\begin{array}{c}0.0399 \\
(0.00513)\end{array}$ & $\begin{array}{c}0.0517 \\
(0.00559)\end{array}$ \\
\hline $\mathbb{I}\{$ Recession $\}$ & $\begin{array}{c}0.39 \\
(0.0477)\end{array}$ & $\begin{array}{c}-0.0242 \\
(0.0534)\end{array}$ & $\begin{array}{c}-0.0161 \\
(0.0558)\end{array}$ \\
\hline $\mathbb{I}\{$ Post Recession $\}$ & $\begin{array}{c}0.183 \\
(0.0865)\end{array}$ & $\begin{array}{l}-0.314 \\
(0.106)\end{array}$ & $\begin{array}{l}-0.477 \\
(0.109)\end{array}$ \\
\hline Trend $\times \mathbb{I}\{$ Recession $\}$ & $\begin{array}{c}0.00538 \\
(0.00471)\end{array}$ & $\begin{array}{c}-0.0151 \\
(0.00575)\end{array}$ & $\begin{array}{c}-0.0204 \\
(0.00644)\end{array}$ \\
\hline Trend $\times \mathbb{I}\{$ Post Rec. $\}$ & $\begin{array}{c}-0.0241 \\
(0.00433)\end{array}$ & $\begin{array}{l}-0.0196 \\
(0.0065)\end{array}$ & $\begin{array}{c}-0.0524 \\
(0.00743)\end{array}$ \\
\hline $\log ($ PI National Brand) & & $\begin{array}{c}32.1 \\
(4.03)\end{array}$ & $\begin{array}{l}23.5 \\
(4.1)\end{array}$ \\
\hline $\log ($ PI Private Label) & & $\begin{array}{c}6.71 \\
(2)\end{array}$ & $\begin{array}{c}3.87 \\
(2.03)\end{array}$ \\
\hline $\log ($ PI All CPG) & & $\begin{array}{l}-33.2 \\
(5.93)\end{array}$ & $\begin{array}{l}-19.7 \\
(6.07)\end{array}$ \\
\hline $\log (\mathrm{CPI})$ & & & $\begin{array}{l}-3.45 \\
(1.13)\end{array}$ \\
\hline $\log$ (PI Gen. Merchandise) & & & $\begin{array}{l}-10.5 \\
(1.36)\end{array}$ \\
\hline Fixed Effects & $\mathrm{HH}$ & $\mathrm{HH}$ & $\mathrm{HH}$ \\
\hline No. Obs. & $1,716,947$ & $1,335,083$ & $1,317,535$ \\
\hline No. Missing & $3,185,575$ & $3,567,439$ & $3,584,987$ \\
\hline No. Clusters & 39,413 & 36,021 & 35,972 \\
\hline$R^{2}$ & 0.576 & 0.583 & 0.585 \\
\hline
\end{tabular}


Table 19: Upper Level Demand: CPG Expenditure System (Food Only and Region Weighted Price Index)

\begin{tabular}{|c|c|c|c|c|}
\hline & $\begin{array}{l}\text { CPG } \\
\text { prices } \\
\text { only }\end{array}$ & $\begin{array}{c}\mathrm{CPG} \\
\text { prices }+ \\
\text { price } \\
\text { proxies }\end{array}$ & $\begin{array}{c}\text { CPG } \\
\text { prices }+ \\
\text { price } \\
\text { proxies }+ \\
\text { trend }\end{array}$ & $\begin{array}{c}\mathrm{CPG} \\
\text { prices }+ \\
\text { price } \\
\text { proxies }+ \\
\text { trend }+4 \\
\text { income } \\
\text { lags }\end{array}$ \\
\hline $\log ($ Income $)$ & $\begin{array}{c}0.0265 \\
(0.0039)\end{array}$ & $\begin{array}{c}0.0246 \\
(0.00388)\end{array}$ & $\begin{array}{c}0.0242 \\
(0.00388)\end{array}$ & $\begin{array}{c}0.0249 \\
(0.00442)\end{array}$ \\
\hline $\log ($ Wealth $)$ & $\begin{array}{c}0.0506 \\
(0.00826)\end{array}$ & $\begin{array}{c}0.0353 \\
(0.00839)\end{array}$ & $\begin{array}{c}0.0072 \\
(0.0093)\end{array}$ & $\begin{array}{l}0.00268 \\
(0.0112)\end{array}$ \\
\hline $\mathbb{I}\{$ Unemployed $\}$ & $\begin{array}{l}-0.00187 \\
(0.00499)\end{array}$ & $\begin{array}{l}-0.00173 \\
(0.00499)\end{array}$ & $\begin{array}{r}-0.000276 \\
(0.00498)\end{array}$ & $\begin{array}{c}0.00933 \\
(0.00601)\end{array}$ \\
\hline $\log (\text { Income })_{-1}$ & & & & $\begin{array}{c}0.0455 \\
(0.00479)\end{array}$ \\
\hline $\log (\text { Income })_{-2}$ & & & & $\begin{array}{c}0.0319 \\
(0.00488)\end{array}$ \\
\hline $\log (\text { Income })_{-3}$ & & & & $\begin{array}{c}0.0183 \\
(0.00514)\end{array}$ \\
\hline $\log (\text { Income })_{-4}$ & & & & $\begin{array}{c}0.00484 \\
(0.00479)\end{array}$ \\
\hline $\log (\mathrm{PI}$ All CPG) & $\begin{array}{c}0.583 \\
(0.0318)\end{array}$ & $\begin{array}{c}1.27 \\
(0.0456)\end{array}$ & $\begin{array}{c}0.71 \\
(0.0788)\end{array}$ & $\begin{array}{c}0.76 \\
(0.0935)\end{array}$ \\
\hline $\log$ (PI Gen. Merchandise) & & $\begin{array}{l}-0.0237 \\
(0.0507)\end{array}$ & $\begin{array}{c}-0.597 \\
(0.0615)\end{array}$ & $\begin{array}{c}-0.601 \\
(0.0714)\end{array}$ \\
\hline $\log (\mathrm{CPI})$ & & $\begin{array}{c}-1.14 \\
(0.048)\end{array}$ & $\begin{array}{c}-1.92 \\
(0.0635)\end{array}$ & $\begin{array}{c}-1.97 \\
(0.0796)\end{array}$ \\
\hline Trend & & & $\begin{array}{c}0.00586 \\
(0.000275)\end{array}$ & $\begin{array}{c}0.00567 \\
(0.00032)\end{array}$ \\
\hline $\mathbb{I}\{$ Recession $\}$ & & & $\begin{array}{c}0.0398 \\
(0.00287)\end{array}$ & $\begin{array}{c}0.0357 \\
(0.00368)\end{array}$ \\
\hline $\mathbb{I}\{$ Post Recession $\}$ & & & $\begin{array}{c}-0.0989 \\
(0.00506)\end{array}$ & $\begin{array}{c}-0.0902 \\
(0.00586)\end{array}$ \\
\hline Trend $\times \mathbb{I}\{$ Recession $\}$ & & & $\begin{array}{l}-0.00688 \\
(0.000304)\end{array}$ & $\begin{array}{l}-0.00641 \\
(0.000361)\end{array}$ \\
\hline Trend $\times \mathbb{I}\{$ Post Rec. $\}$ & & & $\begin{array}{c}-0.00664 \\
(0.000372)\end{array}$ & $\begin{array}{c}-0.0061 \\
(0.000427)\end{array}$ \\
\hline Fixed Effects & $\mathrm{HH}$ & $\mathrm{HH}$ & $\mathrm{HH}$ & $\mathrm{HH}$ \\
\hline No. Obs. & $1,332,396$ & $1,314,940$ & $1,314,940$ & 897,747 \\
\hline No. Missing & $3,570,126$ & $3,587,582$ & $3,587,582$ & $4,004,775$ \\
\hline No. Clusters & 36,021 & 35,972 & 35,972 & 24,441 \\
\hline$R^{2}$ & 0.573 & 0.576 & 0.577 & 0.582 \\
\hline
\end{tabular}

